\title{
Management of Urban Waters with Nature-Based Solutions in Circular Cities-Exemplified through Seven Urban Circularity Challenges
}

\author{
Hasan Volkan Oral ${ }^{1, *(\mathbb{D}}$, Matej Radinja ${ }^{2}(\mathbb{D})$, Anacleto Rizzo ${ }^{3}\left(\mathbb{D}\right.$, Katharina Kearney $^{4}(\mathbb{D}$, \\ Theis Raaschou Andersen ${ }^{5}$ (D), Pawel Krzeminski ${ }^{6}$, Gianluigi Buttiglieri ${ }^{7,8}$, Derya Ayral-Cinar ${ }^{9}$, \\ Joaquim Comas 7,10 (D), Magdalena Gajewska ${ }^{11}$, Marco Hartl ${ }^{12}$ (D), David C. Finger 13,14 (D) Jan K. Kazak ${ }^{15}$ (D), \\ Harri Mattila ${ }^{16}{ }^{(D)}$, Patrícia Vieira ${ }^{17}$ (D) Patrizia Piro ${ }^{18}\left(\mathbb{D}\right.$, Stefania Anna Palermo ${ }^{18}\left(\mathbb{D}\right.$, Michele Turco ${ }^{18}(\mathbb{D})$, \\ Behrouz Pirouz ${ }^{19}$ (D) Alexandros Stefanakis ${ }^{20}$, Martin Regelsberger ${ }^{21}$, Nadia Ursino ${ }^{22}$ \\ and Pedro N. Carvalho $23,24, *$ (D)
}

\section{check for} updates

Citation: Oral, H.V.; Radinja, M.; Rizzo, A.; Kearney, K.; Andersen, T.R.; Krzeminski, P.; Buttiglieri, G.; Ayral-Cinar, D.; Comas, J.; Gajewska, M.; et al. Management of Urban Waters with Nature-Based Solutions in Circular Cities-Exemplified through Seven Urban Circularity Challenges. Water 2021, 13, 3334. https://doi.org/10.3390/w13233334

Academic Editor: Francesco De Paola

Received: 21 October 2021

Accepted: 20 November 2021

Published: 24 November 2021

Publisher's Note: MDPI stays neutral with regard to jurisdictional claims in published maps and institutional affiliations.

Copyright: (c) 2021 by the authors. Licensee MDPI, Basel, Switzerland. This article is an open access article distributed under the terms and conditions of the Creative Commons Attribution (CC BY) license (https:/ / creativecommons.org/licenses/by/ $4.0 /)$
1 Department of Civil Engineering, Faculty of Engineering, İstanbul Aydın University, K. Cekmece, İstanbul 34295, Turkey

2 Faculty of Civil and Geodetic Engineering, University of Ljubljana, 1000 Ljubljana, Slovenia; matej.radinja@fgg.uni-lj.si

3 IRIDRA SRL, 50121 Florence, Italy; rizzo@iridra.com

4 Institute of Sanitary Engineering and Water Pollution Control, University of Natural Resources and Life Sciences, 1190 Vienna, Austria; katharina.kearney@boku.ac.at

5 Research Centre for Built Environment, Energy, Water and Climate, VIA University College, 8700 Horsens, Denmark; Thra@via.dk

6 Norwegian Institute for Water Research (NIVA), N-0579 Oslo, Norway; pawel.krzeminski@niva.no

7 Catalan Institute for Water Research (ICRA), 17003 Girona, Spain; gbuttiglieri@icra.cat (G.B.); Joaquim.comas@udg.edu (J.C.)

8 Universitat de Girona, 17005 Girona, Spain

9 Department of Environmental Engineering, Faculty of Engineering, Gebze Technical University, Gebze 41400, Turkey; deryacinar@gtu.edu.tr

10 The Laboratory of Chemical and Environmental Engineering (LEQUiA), University of Girona, 17071 Girona, Spain

11 EcoTech Center, Department Water and Waste-Water Technology, Faculty of Civil and Environmental Engineering, Gdansk University of Technology, 80-233 Gdańsk, Poland; mgaj@pg.edu.pl

12 Institute for Innovative Phytochemistry \& Closed Loop Processes, Alchemia-Nova GmbH, 1140 Vienna, Austria; marco.hartl@alchemia-nova.net

13 Energy Institute, Johannes Kepler University, 4040 Linz, Austria; davidf@ru.is

14 Department of Engineering, Reykjavik University, 101 Reykjavik, Iceland

15 Institute of Spatial Management, Wrocław University of Environmental and Life Sciences, 50-357 Wrocław, Poland; jan.kazak@upwr.edu.pl

16 HAMK Bio Research Unit, Häme University of Applied Sciences, 30100 Forssa, Finland; harri.mattila@hamk.fi

17 Associação CECOLAB Collaborative Laboratory Towards Circular Economy, 3405-155 Oliveira do Hospital, Portugal; patricia.vieira@cecolab.pt

18 Department of Civil Engineering, University of Calabria, 87036 Rende, Italy; patrizia.piro@unical.it (P.P.); stefania.palermo@unical.it (S.A.P.); michele.turco@unical.it (M.T.)

19 Department of Mechanical, Energy and Management Engineering, University of Calabria, 87036 Rende, Italy; behrouz.pirouz@unical.it

20 Laboratory of Environmental Engineering and Management, School of Chemical and Environmental Engineering, Technical University of Crete, 73100 Chania, Greece; astefanakis@isc.tuc.gr

21 Technisches Büro Regelsberger, 8200 Gleisdorf, Austria; m.regelsberger@aee.at

22 Department of Civil, Environmental and Architectural Engineering (DICEA), University of Padova, 35131 Padova, Italy; nadia.ursino@dicea.unipd.it

23 Department of Environmental Science, Aarhus University, 4000 Roskilde, Denmark

24 WATEC - Centre for Water Technology, Aarhus University, 8000 Aarhus, Denmark

* Correspondence: volkanoral@aydin.edu.tr (H.V.O.); pedro.carvalho@envs.au.dk (P.N.C.)

Abstract: Nature-Based Solutions (NBS) have been proven to effectively mitigate and solve resource depletion and climate-related challenges in urban areas. The COST (Cooperation in Science and Technology) Action CA17133 entitled “Implementing nature-based solutions (NBS) for building 
a resourceful circular city" has established seven urban circularity challenges (UCC) that can be addressed effectively with NBS. This paper presents the outcomes of five elucidation workshops with more than 20 European experts from different backgrounds. These international workshops were used to examine the effectiveness of NBS to address UCC and foster NBS implementation towards circular urban water management. A major outcome was the identification of the two most relevant challenges for water resources in urban areas: 'Restoring and maintaining the water cycle' (UCC1) and 'Water and waste treatment, recovery, and reuse' (UCC2). s Moreover, significant synergies with 'Nutrient recovery and reuse', 'Material recovery and reuse', 'Food and biomass production', 'Energy efficiency and recovery', and 'Building system recovery' were identified. Additionally, the paper presents real-life case studies to demonstrate how different NBS and supporting units can contribute to the UCC. Finally, a case-based semi-quantitative assessment of the presented NBS was performed. Most notably, this paper identifies the most typically employed NBS that enable processes for UCC1 and UCC2. While current consensus is well established by experts in individual NBS, we presently highlight the potential to address UCC by combining different NBS and synergize enabling processes. This study presents a new paradigm and aims to enhance awareness on the ability of NBS to solve multiple urban circularity issues.

Keywords: blue-green infrastructure; climate change and mitigation; sustainable water management; urban circularity challenges; water reuse

\section{Introduction}

Water is a natural and essential resource for human life [1]. Water consumption has doubled in the last century as a result of global population increase, making water scarcity one of the most pressing issues of the twenty-first century [2-4]. Rapid industrialisation and economic growth [5], as well as the generation of substantial amounts of industrial effluents, place a significant strain on limited water resources [6,7]. Climate change is expected to have a significant impact on the water cycle $[8,9]$, resulting in issues in cities such as droughts, floods, water resource pollution, and heat waves [10,11]. Meanwhile, water in urban ecosystems, including wastewater, drinking water, stormwater, groundwater, surface waters, and a variety of urban ecosystems in which water plays a vital role, is currently not treated in a cyclical manner. For example, the regeneration and reuse of wastewater is now a priority only for nations with considerable hydric stress or water shortages (e.g., China, Mexico, the United States, and Israel), yet this regeneration can occur without extra water treatment in some instances [12].

According to the European Commission, more than 40,000 million $\mathrm{m}^{3}$ of wastewater are treated in the EU every year, but only 964 million $\mathrm{m}^{3}$ of this is reused, revealing the potential to increase the volume of reused water by a factor of 6 . In the transition towards Circular Economy (CE), wastewater management and sanitation are central to water circularity and sustainability due to the integration of nutrients and materials recovery, clean water production and energy production [13].

Circular wastewater management would integrate effluent reuse to close the loop between water supply and sanitation. However, a circular water system cannot be limited to merely connecting the outlet of present wastewater treatment plants to the inlet of water supply systems, especially for cities where stormwater management, flood prevention, climate mitigation or greening of the cities is a more pressing issue than water scarcity. It demands a shift towards system thinking, as all urban water issues are intertwined and cannot be sustainably solved by the traditional, siloed water management approaches [14]. The connections between processes can be diverse and the segregation of streams should be optimised in a case-to-case assessment based on local conditions and needs. Ideally, transport and contamination should be minimised, while energy-efficiency and recovery of raw materials maximised [13]. Thus, concepts such as treated effluent reuse in irrigation of commercial crops [15], local use of rainwater and greywater for toilet flushing, car-washing 
and garden irrigation $[1,16]$ or separation of urine and faeces from greywater to maximise nutrient recovery $[13,16]$ are gradually coming to the forefront of the discussion for a circular transition in the water sector. Cities all over the world must rethink and reinvent themselves as water-smart cities, shifting from drained to sponge cities, using reclaimed water and only draining surplus water as a last choice, while still generating chances to green the city and improve liveability [10]. More and more cities thereby consider nature-based solutions (NBS) an integral part of their water management plans. The European Commission defines NBS as: "Solutions that are inspired and supported by nature, which are cost-effective, simultaneously provide environmental, social and economic benefits and help build resilience. Such solutions bring more, and more diverse, nature and natural features and processes into cities, landscapes and seascapes, through locally adapted, resource-efficient and systemic interventions". NBS addresses societal challenges and enables resource recovery, climate mitigation and adaptation challenges, human well-being, ecosystem restoration and/or improved biodiversity status, within the urban ecosystems [17]. NBS can also effectively mitigate the urban flooding caused by high rainfall events $[18,19]$.

The European COST (Cooperation in Science and Technology) Action (CA) 17133 is "implementing nature-based solutions for creating a resourceful circular city" [20]. It emerged as a bottom-up initiative to study and research NBS and their circularity. The main purpose was to test the hypothesis "A circular flow system that implements NBS to manage urban biosphere nutrients and resources, will lead to a resilient, sustainable and healthy urban environment". The CA17133 is structured in five working groups and one has been dedicated to NBS and sustainable urban water utilisation (working group 2), which carried out the work herein presented.

Within the CA17133 seven urban circularity challenges (UCC) were selected [20]: (UCC1) Restoring and maintaining the water cycle; (UCC2) Water \& wastewater treatment, recovery and reuse; (UCC3) Nutrient recovery and reuse; (UCC4) Material recovery and reuse; (UCC5) Food and biomass production; (UCC6) Energy efficiency and recovery; and (UCC7) Building system recovery. These seven UCC provide a novel framework to discuss and plan a transition to circular cities. From the perspective of the UCC, our working group dedicated to urban water identified the following key research questions:

1. From an urban water management perspective, what are the main urban circularity challenges?

2. What are (water) interconnections between the different UCC and how can these UCC be addressed by NBS?

3. What can be learned from current NBS implementations?

4. How can NBS address or contribute to the UCC1 and UCC2?

Looking at what is currently available in the literature containing both NBS and water management as keywords, only a few works directly address the topic. Nika et al. [1] reviewed assessment methodologies, tools and indicators with a focus on societal challenges. Snep et al. [10] reviewed the different technological levels at which city trees and vegetated rooftops have been implemented. Mousavi et al. [21] conducted a survey with Australian water professionals focused on the definition of NBS. Ghafourian et al. [22] provided an analysis of recent literature about the economic impact of linear to circular transition in water systems. All contribute to the topic, but none reflect on any of the research questions herein formulated.

Hence, through a series of nine workshops involving more than 25 experts from several disciplines and 22 European countries, the working group aimed to make a significant contribution to addressing (identified or selected) research questions. This paper presents and discusses the major outcomes of the workshops aimed at fostering NBS implementation. It includes a water-centric conceptualization of the seven UCC, validated with a case-based assessment. Representative NBS units are detailed and discussed linking their functionality with the corresponding challenges they address. The list provides a solid base for a development of a novel case-based semi-quantitative assessment, which enables ranking of all the NBS and supporting units, for both circularity challenge UCC1 and 2. 


\section{Materials and Methods}

The extensive methodology behind this paper, from UCC and NBS selection and definition to NBS circularity characterisation, is fully described by Langergraber et al. [20]. The aim of the methodology is to categorize NBS based on circular economy principles, which are: (1) regenerate natural capital, (2) keep resources in use, and (3) design out waste externalities. The work (Figure 1) is based on a series of five elucidation workshops (adapted from IDEA protocol [23]) conducted between June and December 2020 to (1) refine the list of NBS, according to their ability to fulfill circular economy principles, (2) evaluate the NBS according to their ability to address the UCC; and (3) categorise them based on evaluation [20].

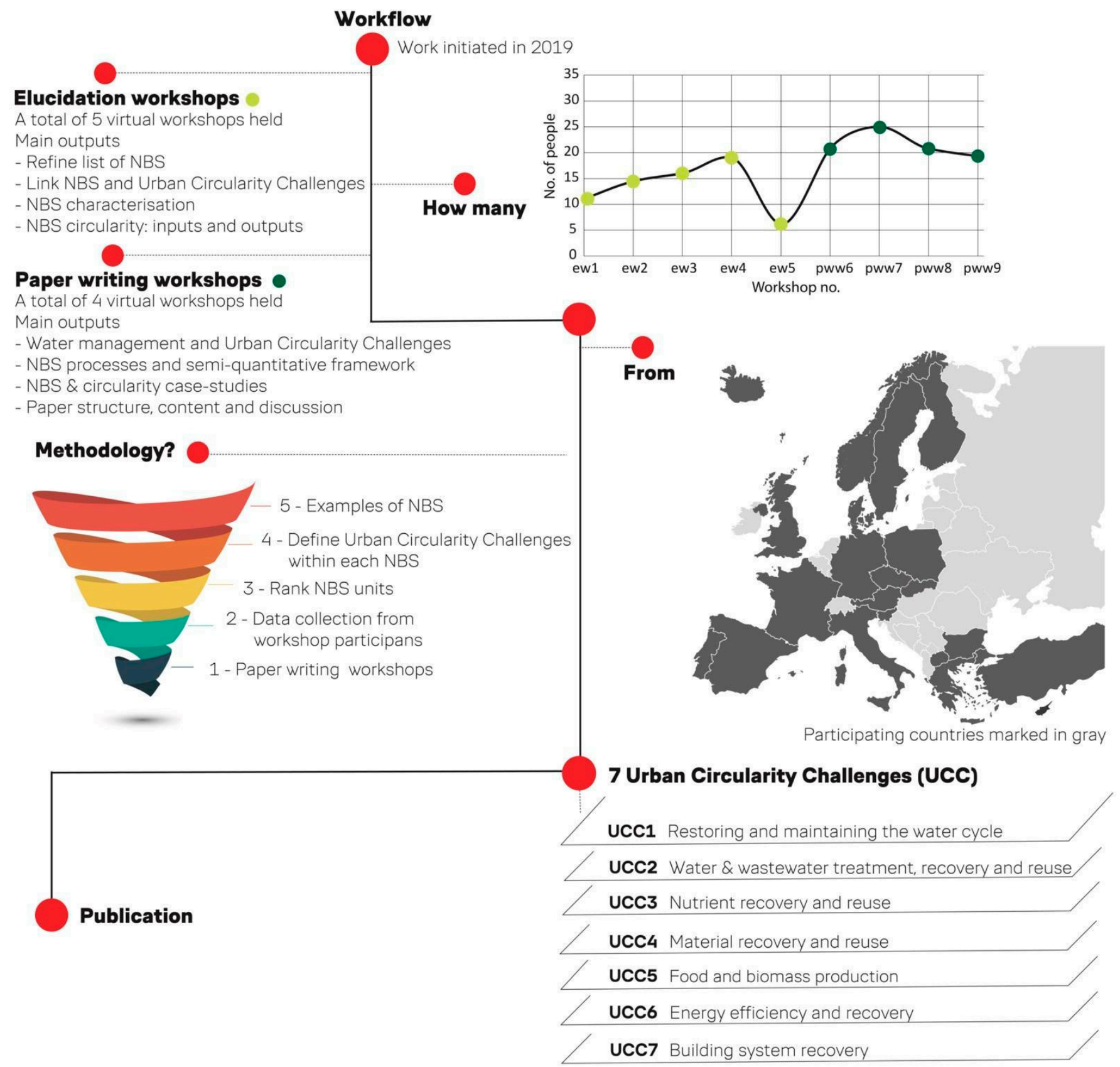

Figure 1. Schematic representation of the processes and workflow, including the details from the elucidation and paper writing workshops. 
The work herein presented is a further expansion of these participative methods which is summarized below.

First, a visual representation of the UCC interconnections was developed based on the experiences of these experts researching and working in water-related fields (Section 3.1). Next, examples (Section 3.2.1) were selected that demonstrate the aforesaid relation based on the expertise and knowledge available in the workgroup (see Table A1). Selected NBS were categorised (Section 3.2.2), by defining a semi-quantitative framework using a three-level scoring system (Table 1). This assessment identifies the overall potential of the NBS units to address or contribute to UCC1 (restoring and maintaining the water cycle) and/or UCC2 (water and wastewater treatment, recovery and reuse). The framework for this ranking was defined to determine the "UCC mark" and a "Total Circularity Score" achieved by each NBS unit or supporting unit:

1. The "UCC mark" (ranging between 1 and 3 ) equals the highest mark awarded to the NBS among one of the enabling processes within each UCC;

2. The enabling process "treatment" within UCC1 equals the highest mark awarded to the NBS among one of the enabling treatment processes within UCC (excluding the 'reuse of water' enabling process);

3. The "Total Circularity Score" achieved by an NBS was calculated as the sum of all awarded individual marks for both UCC1 and UCC2, but excluding the enabling process "treatment" within UCC1, to avoid double-counting.

Table 1. Marking system used for the evaluation of NBS units and supporting units with respect to UCC1 and 2.

\begin{tabular}{cc}
\hline Numerical Mark & Mark Description \\
\hline 3 & Addressing the circularity challenge \\
\hline 2 & Contributing to the circularity challenge \\
\hline 1 & Potential to contribute, depending on specific design \\
\hline
\end{tabular}

\section{Results and Discussion}

\subsection{Urban Circularity Challenges}

Langergraber et al. [20] have outlined a set of seven urban circularity challenges (UCC) directly addressed through NBS implementation in cities. Each UCC is central to achieving circularity, and should be viewed as interdependent objectives in a broader system context. There is an abundant and constant interaction between resources, energy and the needs of the urban population; shedding light on the dynamics at different scales is fundamental to identifying the underlying causes of crises and appropriate points of intervention.

This section examines the interconnections between the UCC with a focus on water systems. Out of the seven UCC, two central challenges relating directly to water in the urban context are addressed in greater detail: (UCC1) restoring and maintaining the natural water cycle, and (UCC2) water and waste treatment, recovery and reuse. Starting from these two central challenges to urban water management, the interconnections with the remaining challenges are analysed and outlined. This includes practical experiences in linking various domains such as urban agriculture, energy production, infrastructure and resource recovery.

\subsubsection{Urban Circularity Challenges (UCC) with a Focus on Urban Water}

Figure 2 shows the seven UCC identified as critical issues in achieving circularity in cities, which can be addressed through various NBS. The diagram depicts the links between the challenges, categorised as either directly or indirectly relating to the topic of water. Blue arrows indicate a direct link to urban water, while grey arrows signify connections in a broader context, such as contributions to climate change mitigation, reducing dependency on natural resources, and/or the reduction of our reliance on fossil fuels. The gradient 
arrow (blue-grey) connects UCC1 to the outer circle, which stands for contributions to climate regulation and possible mitigation effects in weather extremes, urban heat island effect, air pollution and climate change. Bi-directional arrows indicate an exchange or a flow path in both directions, while the simple one-directional arrows represent a one-way path from one element (challenge) to another. There are likely to be bi-directional flows between each of the system elements, but for the sake of simplicity, only the primary path directions are depicted in this diagram.



Figure 2. Diagram illustrating the interconnections between the seven circularity challenges from the perspective of urban water. The two central challenges of our analysis are (UCC1) restoring and maintaining the water cycle, and (UCC2) water and waste treatment, recovery and reuse.

Some of the connections between the UCC are obvious and already common practice such as rainwater harvesting for watering purposes and nutrient recovery from wastewater to be used as fertiliser [24]. Other connections are less evident and not yet well established such as recovering material from wastewater for use in construction $[25,26]$.

\subsubsection{Restoring and Maintaining the Water Cycle (UCC1)}

Urban circularity challenge is related to the goal of restoring the natural water balance as far as possible. Built-up, urban environments are characterised by a drastically altered water balance, compared to that of undeveloped, natural landscapes. Sealed-off and hydraulically smooth surfaces combined with little to no vegetation result in higher runoff volumes and peaks, along with significantly lower proportions of infiltration and evaporation [27]. Climate change is expected to exacerbate this disturbed water balance. NBS are ranked as interventions with high manageability and high impact in terms of reducing flood risk in urban areas [11]. Measures to promote permeability are also included in this category [28]. By implementing NBS throughout the city, it is possible to begin re-establishing a more natural water balance, reducing runoff peaks and volumes and promoting infiltration, retention and evapotranspiration [29]. Groundwater recharge is an important factor in securing the drinking water supply of many cities [30]. Urban greening interventions can contribute to groundwater recharge by facilitating infiltration processes [31] and land restoration can increase the water holding capacity of natural land upstream of urban areas [32]. Increased evapotranspiration and mitigation of the urban heat island effect can be achieved by the planting of trees and other vegetation along roadsides [33], in rain gardens [34], meadows [35,36], green roofs and green facades [37]. A majority of the studies have shown the beneficial effects of green roofs in delaying the 
peak flow rate and reducing the total runoff volume discharged into combined sewer systems [38-40]. A wide array of NBS can contribute to restoring the natural water balance, including various infiltration and retention options. For a more detailed list, the reader is referred to Section 3.2.

\subsubsection{Water and Waste Treatment, Recovery and Reuse (UCC2)}

Urban circularity challenge 2 addresses the matter of recovering rainwater and reusing wastewater to reduce the consumption of clean drinking water, while relieving urban drainage infrastructure and treatment facilities and protecting downstream freshwater from the pollutants contained in runoff water, blackwater and greywater.

NBS has changed the approach of dealing with urban water [41]. The concept of circularity dictates focussing not only on waste valorisation (i.e., through treated wastewater reuse), but also on the treatment process itself, by using eco-designs such as the various NBS systems [29]. NBS as urban green infrastructure provides sustainable solutions to the pressing issue of water management in urban and peri-urban areas. For example, the rise of the constructed wetland technology shows that wastewater management is viewed from a different angle; the goal is no longer one-dimensional (wastewater treatment), but extends to the provision of multiple benefits such as ecosystem services, habitat creation sites, urban wildlife refuges, recreation and landscaping [42,43].

Rainwater, in particular, is a valuable resource for local uses such as gardening, washing cars and laundry. Rainwater harvesting can reduce reliance on groundwater and other freshwater sources, for uses that do not demand the high-quality standards of drinking water. Utilising local water resources can increase urban resilience in regards to UCC1, complementing and relieving large-scale water supply systems that are susceptible to failure. Intercepting and harvesting the water from precipitation before it forms runoff in the urban catchment not only presents an additional, low-cost water source, but also contributes to re-establishing the pre-development water cycle $[44,45]$. Dual-use rainwater harvesting systems are in this context relevant for combining stormwater management and additional water supply [45].

In the context of UCC2, the central idea is to adopt a 'fit-for-purpose' approach in water use. Instead of treating all used water streams equally, conveying them in combined sewers and putting undue pressure on the treatment facilities, a circular water system is conceived to differentiate between varying sources and qualities of water. Recycling household greywater for laundry and other washing purposes, along with rainwater harvesting, are common examples of this approach. A significant barrier to operationalising this on a citywide scale is the requirement for adapted piping in buildings. Retrofitting large parts of the existing infrastructure would be an expensive and logistically challenging undertaking, although it can be considered a good opportunity for replacing ageing infrastructure for implementing circular systems. Public perception in regards to domestic water reuse may present a more significant barrier [46,47].

\subsubsection{Nutrient Recovery and Reuse (UCC3)}

Urban circularity challenge 3 addresses the need for nutrient recovery and reuse. In the context of urban water, this relates specifically to the nutrients present in used water streams, and the different systems for recovering these nutrients. Fertiliser production is a prominent example of recovering nutrients from used water streams. This has the added benefit of preventing eutrophication in downstream freshwaters [48].

Non-grid, small-grid and hybrid urban wastewater systems permit source separation and optimisation of water management and use. Blackwater from toilets and greywater from sinks, showers and washing machines can be collected separately for onsite treatment or for non-potable water uses. Reuse options for greywater include toilet flushing, infiltration for aquifer recharge or irrigation. Sludge can be collected for centralised treatment. Urine diverting dry toilets are another option for collecting urine for onsite treatment 
and conversion into fertilizer, for use in urban agriculture. Similarly, brown water and greywater can be collected in a single stream for centralised treatment [49].

There is a strong link between UCC 3 and the two central water challenges, UCC1 and 2. The potential for reclaiming nitrogen and phosphorus from household wastewater through a range of different processes, such as source separation or fertiliser production from sewage sludge, is well established and should be further promoted [50].

\subsubsection{Material Recovery and Reuse (UCC4)}

Urban circularity challenge 4 concerns the materials pathways and the possibilities for recovery and reuse within the urban environment. The main link identified with the central water challenges is the connection from UCC 2 to 4 . Wastewater has gained attention in recent years, as a source not only of nutrients, but also raw material for various other products.

Wastewater sludge and incineration ashes have been used successfully in the production of construction material, consisting either in part or whole of recovered material. Alayish and Çelik [51] report the use of dewatered sludge from a local water treatment facility to produce a viable, artificial lightweight building aggregate. This recovered material presents an alternative to conventional cement, and solves the issue of surplus sludge disposal [51]. Bioplastics, paper and cellulose are other examples of products that can be produced from used water sludge [52]. Protein recovery and feed production can be achieved through gas-phase processing and metals can be recovered from sludge for reuse in various industries. Moreover, raw materials for pharmaceutical and human health products have also been recovered from dewatered sludge [50].

Although the technical possibilities are growing, there is still a lag in large-scale implementation for various reasons, including technical immaturity and non-technical bottlenecks. Resource recovery is often possible only on a small scale and quality control can be difficult to implement. Consequently, there is no competitive advantage with many recovered products compared against their conventionally produced counterparts [47]. Dimensions of scale, consumer acceptance and stringent quality requirements can further inhibit the shift to material recovery from used water streams [50,52].

\subsubsection{Food and Biomass Production (UCC5)}

Urban circularity challenge 5 can be linked to urban water in two directions and with both direct and indirect interdependencies. Water is an essential resource for growing food, and the presence of plants in the urban environment, in turn, affects the local water balance through evapotranspiration, infiltration and runoff mitigation. Localised food production systems can profit from recovered water for irrigation purposes and utilise fertiliser produced from used sewage sludge or household wastewater streams. Rainfed farming, an alternative option for irrigating urban crops, is another point of connection to UCC1, as disturbed precipitation patterns may cause difficulties in cases of drought or extreme rain events, if the urban farming system relies on rainwater harvesting as the primary source of water [53]. Restoring and maintaining the water cycle will have favourable impacts on any aspect of food and biomass production, such as regular rainfall, increased humidity, moderate temperature peaks and flood reduction.

Improved micro-climates and soil moisture content also play a role in regulating the temperature within buildings (e.g., by green roofs or green walls) and in the environs, reducing the reliance on non-renewable energy sources for heating and cooling purposes [54,55], thus linking food and biomass production in the urban environment to the outer circle in Figure 2, through contributions to climate change mitigation and climate regulation.

\subsubsection{Energy Efficiency and Recovery (UCC6)}

Urban circularity challenge 6 has also been identified as having a strong two-way link to urban water, both to UCC1 and UCC2. Often described as the water-energy nexus, water and energy are interlinked in terms of resource use [56,57]. The water-energy 
nexus should be considered during the whole life cycle of resources and products. For instance, water is required for energy production, while energy is essential for water extraction, distribution, and treatment $[58,59]$. The residual heat in wastewater streams can be harnessed to contribute to improved energy efficiency. Greywater can also be reused for cooling purposes, reducing the need for fossil fuels used in conventional air conditioning units. The methane generated in sludge treatment facilities from anaerobic digestion is a valuable, closed-loop energy source that also contributes positively to the challenge of energy efficiency and recovery [60-62]. The recovery of organic residual streams from wastewaters can be a valuable resource for biogas production [48,63]. Anaerobic digestion of residuals of wastewater can enhance the production of carbon neutral biogas, methanol biodiesel or their bio-energies [64]. The production of bio-energies from organic residuals in wastewater requires large water treatment infrastructure, and is thus suitable only for larger urban areas.

Energy demand may be further reduced by implementing NBS for rainwater harvesting and management, for example, by using vertical green infrastructure and green roofs. NBS can be applied to mitigate the issues related to climate change and ongoing urbanisation in line with the water-energy nexus [57]. The implementation of NBS from the category of urban greening (i.e., green roofs, green walls, parks, rain gardens etc.) helps to mitigate the urban heat island effect [19]. It improves the thermal performance at building scale, thereby reducing the need for conventional air conditioning, and provides energy savings for the heating of buildings, both with the use of green walls [65] or green roofs [66-68].

\subsubsection{Building System Recovery (UCC7)}

Urban circularity challenge 7 is related to urban water directly through UCC1, and indirectly through climate and resilience improvements related to NBS implementations from the urban water repository. Many of the NBS discussed in relation to urban water are directly connected to buildings, such as green roofs, green facades, living walls, and in some cases even building-integrated constructed wetlands. Further, conventional ways of building have contributed largely to the altered flow regime of rivers and urban streams and the disturbed water balance in urban catchments. The impervious paving alters runoff formation and may lead to increased pollution in stormwater runoff [69]. In this way, building systems are inextricably linked to the water cycle and urban water management on a smaller scale.

According to the path dependence theory, decisions from our past pave the way for future development $[70,71]$. When it comes to water in cities, the existing path has supported the development of linear systems over circular ones. Given the limited available urban space, it is evident that any given NBS solution should be conceived, designed, constructed and operated such that its contributions towards overcoming the seven circularity challenges are maximized. Consideration of the connections between these challenges and the way they relate to each other will offer a clearer picture of how to exploit synergies for a faster transition to circularity in cities.

\subsubsection{Crucial Challenges for Water Management}

NBS for water management are traditionally implemented to increase water availability, improve water quality and mitigate water related risks [72]. Thus, UCC1 and UCC2 were identified as the central challenges in this context, and selected for a more in-depth analysis. However, hydraulic risk mitigation and water quality maintenance do not always adhere to circularity. Water management has a two-way influence on the economy and society and may be a decisive factor for environmental sustainability, and consequent economic development [73]. To facilitate future integration of NBS in circular urban schemes, there is a need to understand the different NBS units in a multidisciplinary perspective. The presently proposed integration of water into the different UCC (Section 3.1) and the identi- 
fication of key processes for water management (Section 3.2.2), are expected to facilitate the transition towards circular urban schemes.

\subsection{Achieving Circularity Challenges with NBS}

\subsubsection{Case-Based Assessment}

In order to confirm the previous theoretical analysis, known examples of NBS in cities were listed and analysed. This included validating the interconnection between the key UCC1 and UCC2 for water management in circular cities, as well as with other UCCs. Table A1 (see Appendix A) summarizes examples of the described NBS units. The examples represent a wide range of applications, highlight the UCC addressed by the NBS examples, and give information of the several additional benefits that can be delivered by implementing a particular NBS. The listed real-life NBS confirm the validity of the UCC-NBS framework proposed. They highlight the circularity of NBS regarding the key water challenges (UCC1 and UCC2), and demonstrate potential synergies with other UCCs already successfully addressed by NBS. Moreover, compiling these examples has helped reveal current needs. Firstly, the need for a broader database in which the NBS role in urban circularity is collected in a more structured way, including worldwide cases with particular attention given to full-scale systems. The need for such an NBS dataset is emerging and several datasets of NBS are being proposed, as recently reviewed [74] or as represented by the recent SNAPP dataset [75]. Secondly, the collection of examples should be accompanied, wherever possible, by quantification of their contribution to addressing circularity challenges, and the corresponding enabling processes and, as a result, should replace more and more simple qualitative evaluation. There is a need to provide a systematic overview of the functionalities of NBS and supporting units, as provided in this study, and to demonstrate the importance of their implementation. It is also important to point out that NBS are often designed as a set of complementary and connected units [76] and each NBS unit can be essential, in some cases even with only one enabling process.

\subsubsection{Enabling Processes}

Individual NBS and supporting units usually contribute to at least one or several urban circularity challenges (UCC). This is achieved by providing different physical, biological and chemical processes $[77,78]$ or by enabling the reuse and recovery of water. The processes that certain NBS provide or employ are inherently connected with their purpose and contribution to achieving UCC. The most typical processes employed by NBS units for restoring and maintaining the water cycle (UCC1) are presented and described in Table 2, with examples of NBS units. Six enabling processes for UCC1 were selected: conveyance, infiltration, detention, retention, evapotranspiration and treatment.

In terms of water treatment, water recovery, and water reuse (UCC2), the processes most typically employed by NBS units are presented in Table 3: sedimentation, filtration, uptake by plants, biodegradation, photo-degradation, sorption, other treatments and reuse of water. Water treatment and water recovery are not represented as stand-alone enabling processes, as they typically consist of a set of combined processes (e.g., treatment train). Thus, all the enabling processes presented, except for the reuse of water, can be used to achieve water treatment or recovery (e.g., sedimentation, filtration, etc.) by different NBS units and supporting units. This way, they are also related to the enabling process of water treatment presented in UCC1, where they can contribute to the restoration and maintenance of the urban water cycle. On the other hand, reuse of water enables the previously captured and/or treated water to be used again typically for irrigation purposes (e.g., vertical green infrastructure \& green roofs, greening interventions \& green space) or groundwater recharge (e.g., infiltration basin, infiltration trench). 
Table 2. Enabling processes for achieving UCC1: restoring and maintaining the water cycle.

\begin{tabular}{|c|c|c|}
\hline Enabling Process & Process Description * & NBS Unit Example \\
\hline Conveyance & Transport of water. & Filter strip, bioswale, dry swale \\
\hline Infiltration & $\begin{array}{c}\text { Flow of water through the ground surface into soil } \\
\text { or a porous medium. }\end{array}$ & $\begin{array}{c}\text { Infiltration trench, infiltration basin, vegetated } \\
\text { grid pavement }\end{array}$ \\
\hline Detention & $\begin{array}{c}\text { Temporary storage of precipitation which is en route } \\
\text { to, or in, the stream/channel system, during or } \\
\text { shortly after rainfall. }\end{array}$ & $\begin{array}{l}\text { Intensive green roof, rainwater harvesting, (dry) } \\
\text { detention pond, floodplain }\end{array}$ \\
\hline Retention & $\begin{array}{l}\text { Permanent storage of precipitation which is en route } \\
\text { to, or in, the stream/sewer system. }\end{array}$ & (Wet) retention pond \\
\hline Evapotranspiration & $\begin{array}{l}\text { Water transferred from the soil to the atmosphere by } \\
\text { evaporation and plant transpiration. }\end{array}$ & $\begin{array}{l}\text { Bioretention cell (rain garden), urban forest, tree } \\
\text { pits, extensive green roof }\end{array}$ \\
\hline Treatment & $\begin{array}{l}\text { Changing harmful or undesirable physical and } \\
\text { chemical properties of water by removing harmful } \\
\text { and undesirable substances and living organisms. }\end{array}$ & Treatment wetland, waste stabilisation pond \\
\hline
\end{tabular}

Table 3. Enabling processes for achieving UCC2: water-treatment, recovery, and reuse.

\begin{tabular}{|c|c|c|}
\hline Enabling Process & Process Description * & NBS Unit Example \\
\hline Sedimentation & $\begin{array}{c}\text { Process of settling and depositing suspended matter in } \\
\text { water by gravity. }\end{array}$ & Infiltration basin, Waste stabilisation pond \\
\hline Filtration & $\begin{array}{l}\text { Process of passing a liquid through a filtering medium } \\
\text { for the removal of suspended or colloidal matter. }\end{array}$ & Filter strip, riparian buffer, treatment wetland \\
\hline Uptake by plants & $\begin{array}{c}\text { Transfer of substances from the environment to plant } \\
\text { tissue/structure. }\end{array}$ & $\begin{array}{l}\text { Bioretention cell (Rain garden), } \\
\text { phytoremediation }\end{array}$ \\
\hline Biodegradation & $\begin{array}{l}\text { Biochemical transformation of substances using } \\
\text { microorganisms, mostly bacteria, to stable end products. }\end{array}$ & Treatment wetland, waste stabilisation pond \\
\hline Photo-degradation & $\begin{array}{c}\text { Process of degradation of substances exposed to } \\
\text { sunlight ultraviolet radiation. }\end{array}$ & (Wet) Retention pond/Waste stabilisation pond \\
\hline Sorption & $\begin{array}{l}\text { Includes the processes of adsorption and absorption by } \\
\text { which some substances become attached to another (soil, } \\
\text { sludge or plants). }\end{array}$ & Intensive green roof, anaerobic treatment \\
\hline Other treatments & $\begin{array}{l}\text { Phosphorus precipitation; ammonia stripping; chemical } \\
\text { disinfection; pyrolysis; advanced oxidation. }\end{array}$ & Supportive units \\
\hline Reuse of water & $\begin{array}{c}\text { To use water again especially in a different way or after } \\
\text { recovery/treatment. }\end{array}$ & Productive garden, street trees \\
\hline
\end{tabular}

$$
*[77,78] \text {. }
$$

\subsubsection{Assessment of Total Circularity Scores}

Based on the aforesaid processes (Tables 2 and 3) the 51 NBS and 10 supporting units [20] were semi-quantitatively ranked (described in Section 2) based on the extent to which they can contribute to address UCC1 and UCC2. The qualitative assessment of NBS units provides a systematic overview of their functionalities and demonstrates the importance of their implementation. For each NBS unit and enabling process, a mark value of 3, 2 or 1 was assigned when the NBS unit addresses, contributes or could potentially contribute, depending on the design, to the UCC1 and UCC2, respectively. To facilitate the interpretation of these results a shorter list of 12 selected representative NBS covering different sub-categories was formed (as can be seen in Table 4). The full dataset is included as Table A2. 
Table 4. Case-based (Table A1) qualitative assessment of the 12 selected NBS units.

\begin{tabular}{|c|c|c|c|c|c|c|c|c|c|c|c|c|c|c|c|c|c|}
\hline \multirow{4}{*}{ Sub-Category } & \multirow{4}{*}{ NBS Unit } & \multirow{4}{*}{$\begin{array}{c}\text { Total } \\
\text { Circularity } \\
\text { Score } 1,2\end{array}$} & \multicolumn{15}{|c|}{ Urban Circularity Challenge } \\
\hline & & & \multicolumn{7}{|c|}{ UCC1: Restoring and Maintaining the Water Cycle } & \multicolumn{8}{|c|}{ UCC2: Water-Treatment, Recovery, and Reuse } \\
\hline & & & \multirow{2}{*}{$\begin{array}{l}\mathrm{UCC}^{\mathrm{UCC}} \\
\text { Mark }^{3}\end{array}$} & \multicolumn{6}{|c|}{ Enabling Process } & \multirow{2}{*}{$\begin{array}{l}\text { Mark2 }^{3} \\
\text { Mark }^{3}\end{array}$} & \multicolumn{7}{|c|}{ Enabling Process } \\
\hline & & & & $\begin{array}{l}\text { Conve- } \\
\text { yance }\end{array}$ & Infiltration & Detention & Retention & Evapotrans. & Treatment & & Sedimentation & Filtration & $\begin{array}{l}\text { Uptake by } \\
\text { Plants }\end{array}$ & $\begin{array}{c}\text { Bio- } \\
\text { Degradation }\end{array}$ & $\begin{array}{c}\text { Photo- } \\
\text { Degradation }\end{array}$ & Sorption & $\begin{array}{c}\begin{array}{c}\text { Reuse of } \\
\text { Water }\end{array} \\
\end{array}$ \\
\hline \multirow{4}{*}{ Units for rainwater management } & Infiltration trench & 7 & 3 & & 3 & & & & 1 & 1 & & 1 & & 1 & & 1 & 1 \\
\hline & $\begin{array}{l}\text { Bioretention cell } \\
\text { (Rain garden) }\end{array}$ & 16 & 3 & & 1 & 3 & & 3 & 3 & 3 & 3 & 1 & 3 & & 1 & 1 & \\
\hline & Dry swale & 6 & 3 & 3 & 2 & & & & 1 & 1 & & 1 & & & & & \\
\hline & Riparian buffer & 19 & 3 & 3 & 3 & 3 & & 3 & 3 & 3 & 1 & 2 & 3 & & & 1 & \\
\hline \multirow{2}{*}{$\begin{array}{c}\text { Vertical Green Infrastructure \& } \\
\text { Green Roofs }\end{array}$} & $\begin{array}{l}\text { Extensive green roof } \\
\end{array}$ & 6 & 3 & & & 1 & & 3 & 1 & 1 & & & 1 & & & 1 & \\
\hline & Intensive green roof & 15 & 3 & & & 3 & & 3 & 2 & 2 & & 1 & 2 & 2 & & 2 & 2 \\
\hline $\begin{array}{l}\text { Remediation, Treatment \& } \\
\text { Recovery }\end{array}$ & $\begin{array}{l}\text { Anaerobic treatment } \\
\text { (for nutrient, VFA \& } \\
\text { methane recovery) }\end{array}$ & 3 & 3 & & & & & & 3 & 3 & & & & 3 & & & \\
\hline \multirow[b]{2}{*}{ River Restoration } & River restoration & 24 & 3 & 3 & 3 & 3 & & 3 & 2 & 2 & 2 & 2 & 2 & 2 & 2 & 2 & \\
\hline & $\begin{array}{l}\text { Coastal erosion } \\
\text { control }\end{array}$ & 2 & 2 & 2 & & & & & & & & & & & & & \\
\hline $\begin{array}{l}\text { Greening intervention + (Public) } \\
\text { Green Space }\end{array}$ & Large urban park & 14 & 3 & & 3 & 3 & & 3 & 1 & 3 & & 1 & 1 & & & & 3 \\
\hline $\begin{array}{l}\text { NBS units for food \& biomass } \\
\text { production }\end{array}$ & Productive garden & 12 & 3 & & 3 & 2 & & 3 & 1 & 3 & & & 1 & & & & 3 \\
\hline
\end{tabular}

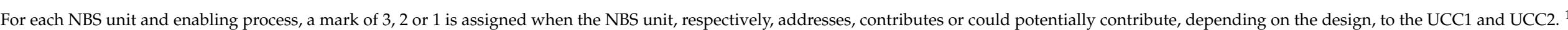

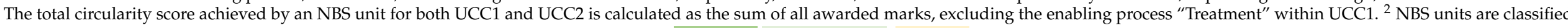

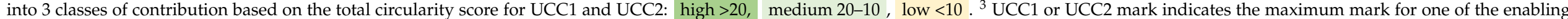
processes, that the particular unit was assigned. 
Based on this semi-quantitative analysis, the NBS units with the highest total circularity score were river restoration, reconnection of oxbow lake and floodplain (restoration units), treatment wetlands (remediation, treatment, and recovery unit) and riparian buffer (rainwater management unit). Considering the total circularity score, $8 \%$ of the NBS units were assigned a score higher than 20 (out of a maximum of 36), which can be considered as highly contributing units, while $37 \%$ achieved a score between 10 and 20, regarded as units with medium impact. Finally, among the 51 NBS units, 55\% (28 units) achieved a score lower than 10. Thus, if implemented as stand-alone units, they are anticipated to have a limited contribution to UCC1 and UCC2. All the supporting units (a total of 10) used for rainwater management, remediation, treatment, and recovery achieved a score lower than 10 and thus, have a low impact on UCC1 and UCC2 on a stand-alone basis.

Rainwater management units are ranked with low to medium impact. Among them, the riparian buffer and the bioretention cell (or rain garden) are the most effective ones to face the UCC1 and UCC2, whereas infiltration trench and dry swale are found to be the least effective. The riparian buffer and the bioretention cell can better tackle restoring and maintaining water cycle challenge UCC1 because the presence of vegetation enables processes such as detention, evapotranspiration, and treatment. The riparian buffer, in particular, can largely contribute to infiltration, conveyance and detention, and is the most effective NBS unit to face UCC1. Evaluating the contribution of these four NBS units to UCC2 we find that the main difference stems from the uptake by plants in the treatment enabling processes. The riparian buffer and the bioretention cell are also able to address UCC2, while the infiltration trench and the dry swale have only potential contribution to UCC2.

Vertical green infrastructures and green roofs are determined as units with low to medium impact on UCC1 and UCC2. Intensive green roofs are ranked as the highest, and extensive green roofs as the lowest. Though both versions of green roofs address the UCC1 equally, the extensive green roof contribution to UCC2 is limited compared to intensive green roofs. Intensive green roofs have higher detention and treatment due to a deeper soil layer, greater variety of vegetation, and installation and maintenance operations such as irrigation and fertilisation. Further, intensive green roofs enable treatment processes such as filtration, microbiological treatment and uptake by plants and sorption. Finally, intensive green roofs can be irrigated with treated water, thus contributing to water reuse [79]. Thus, UCC2 is addressed better by intensive roofs. This example illustrates that the contributions of certain NBS to the UCC 1 and 2 can largely differ, based on the NBS design.

Remediation, treatment, and recovery units have a wider range in terms of contribution to UCC1 and UCC2 because high, medium, and low impact units coexist in this group. Aerobic and anaerobic treatment units can provide only microbiological treatment whereas treatment wetlands also enable processes such as sedimentation, filtration, uptake by plants, sorption, and degradation by solar radiation [42]. Besides, treatment wetland is the most effective treatment because it provides detention, retention and evapotranspiration of water. Consequently, these units have noticeably different contributions to both UCC1 and UCC2.

River restoration units are composed of high- and low-contributing units simultaneously. River restoration is found to be a highly contributing NBS unit with conveyance, infiltration, detention, evapotranspiration and treatment functionalities, thus contributing largely to UCC1. Additionally, river restoration units can face UCC2 through all the wastewater treatment enabling processes. However, coastal erosion control can provide only conveyance. Therefore, its role as a single unit is only transporting water, and it needs to be combined with other units to address UCC1. Moreover, they are not considered relevant in terms of waste and water treatment, recovery and reuse.

Greening intervention units are ranked with medium impact whereas units for food and biomass production are determined to have lower or medium impact. Large urban parks as a greening intervention and productive garden as food and biomass production units are mostly important for UCC1 through infiltration, detention and evapotranspi- 
ration. However, they are not the most effective in addressing UCC2 because they lack water treatment capacity. Nevertheless, their potential should not be disregarded, due to their function in enabling the reuse of the treated water. This calls for the relevance of understanding which inputs and outputs are needed or can be used among the different units.

Every process realised or facilitated by NBS which achieves UCC1 has the potential to transform water into a reusable resource. Water conveyance achieves circularity when it is redirected to gardens, cultivated areas, or the subsoil, where it is stored for future use or recharges surface water bodies, preserving a minimum flow in the face of prolonged drought, increasing the water storage capacity in urban soils and enhancing the respective ecosystem service [80]. Similarly, infiltration increases the water stock in subsurface water bodies. Detention, when paired with reuse, can be effective from a circular economy perspective, and retention can achieve both the circularity goals of infiltration and detention systems. When evapotranspiration coincides with crop production or useful plant growth, the water cycle becomes a circular economy tool. Water reuse is made possible by using NBS treatment to achieve adequate water quality (UCC2). NBS which address (waste)water treatment by sedimentation, filtration, microbiological treatment and degradation of contaminants or water recovery, thus support addressing circularity. Moreover, by reusing water to feed NBS, circularity is achieved by closing the loop and recovering water and potentially nutrients cycling back to UCC1 and the preservation of the water cycle. Apart from aspects relating to the hydrological cycle, water reuse and treatment, a water-centered perspective of urban circularity must also consider the matters of nutrient recovery, material recovery, food and biomass production, the water-energy nexus, and examining the built-up environment.

The NBS discussed here are highly effective and promising systems to address the UCC, but their contributions to circularity will rely heavily on the extent of their implementation, the consistency and appropriateness of their operation and maintenance schemes and, perhaps most important, their acceptance and recognition by citizens and the society at large. The proposed semi-quantitative categorisation of NBS units (Tables 4 and A2) is intended as a tool to support this transition.

The quantification of other types of ecosystem services, especially those related to biodiversity, and social and economic aspects, remains an open issue under research. For example, the role of NBS in psychological health and the overall well-being has recently been studied [81]. There is a distinct lack of examples in which ecosystem services or co-benefits are quantified, while most of the time they are indicated qualitatively or, when quantified, they are hardly comparable due to the use of several different evaluation frameworks $[82,83]$ and databases [84-86]. This could be related to the lack of standardization in monitoring NBS performance and NBS benefits. However, this will hopefully improve with the new handbook published by the European Commission [87], which provides a comprehensive NBS impact assessment framework and a robust set of indicators and methodologies to help decision makers and practitioners assess the impact of NBS [88]. Ecosystem service evaluation [89] and monetisation (e.g., [90]) can also play a relevant role.

Despite the recent advances in NBS concepts and deepening insights we now have on the benefits of NBS for a circular economy, there is a gap between the implementation and fundamental understanding of their role in a circular city. Only 70 out of the 167 nationally determined contributions submitted under the Paris Agreement include NBS actions, the majority of which are in low-income countries [91]. However, it should also be noted that in more than 20 tropical countries, NBS implementation is relatively high, putting them on track to achieving carbon neutrality before $2030[15,69]$. Thus, the potential of NBS to provide multiple economic, environmental and social benefits is not yet fully utilised [92].

To overcome the different barriers identified in this study, we reiterate a series of recently proposed actions [11,93]: (i) raise awareness on nature's value, through collaboration and experience exchange across different stakeholders, facilitated by governments, civil society organisations, and the private sector; (ii) integrate NBS into climate adaptation 
plans and circular economy strategies; (iii) encourage investment in NBS, by developing new funding streams and models that can support long-term investment, including private sector actors, modifying governmental policies, subsidies, and public investments and providing better incentives for private investors to finance NBS projects; and (iv) integrate NBS in financial conditions, procurement, industry standards and other policies to link the current challenges with the available solutions and expertise.

Circularity is a new way of planning water management by use of multiple and interconnected solutions aimed at restoring or creating water, materials and energy cycles [94-96]. In this respect, the present work provides a multidisciplinary overview of different NBS and tries to raise the awareness of the potential of NBS to address multiple urban circularity challenges.

\section{Conclusions}

This collaborative paper provides a water-centric perspective on how to address the CA17133 seven urban circularity challenges (UCC), while bolstering resilience and enabling circularity with NBS. The interconnections between the different UCC were discussed and demonstrated with case studies selected based on the expertise and knowledge available in the workgroup.

The multifunctionality of the 51 NBS and 10 supporting units have been assessed and linked with the UCC and their interconnections. The potential applicability of NBS units and supporting units to address the two water-centered UCCs, UCC1 and UCC2, was assessed for the first time using a semi-quantitative methodology. Among the 61 units, the NBS circularity scoring identified three highly contributing units and 20 medium contributing units towards addressing the UCC. The provided semi-quantitative categorisation can be used as a tool to support wider implementation of the NBS to address UCC common for many cities. The proposed circularity ratings, which identify critical processes for water management, are anticipated to help in the adoption of NBS to achieve sustainable urban water management.

In order to better confront the varied and complex difficulties presented by the UCCs, the provided interdisciplinary, collaborative approach made use of participant knowledge, experience, and expertise relating to water management and NBS. However, our analysis reveals that the multifunctionality of NBS in a multidisciplinary perspective is not fully understood. Current NBS knowledge has to be broadened beyond professionals to include non-specialists and key stakeholders. By considering practical, real-world examples and incorporating a diverse group of informants, comparable approaches involving non-experts can be effective in preventing an unduly techno-centric and siloed vision of water management. Accordingly, we recommend to focus further research on the quantification of ecosystem services (related to biodiversity, social and economic aspects), in order to bridge the gap between the implementation and fundamental understanding of the role of NBS in a circular city.

Author Contributions: Conceptualization, organization of the work and editing H.V.O. and P.N.C.; sub-group work, data curation and first draft was facilitated by M.R. (Matej Radinja), A.R., A.S. and K.K., data curation, T.R.A., investigation, P.K., G.B., D.A.-C., J.C., M.G., M.H., D.C.F., J.K.K., H.M., P.V., P.P., S.A.P., M.T., B.P., M.R. (Martin Regelsberger) and N.U. All authors have read and agreed to the published version of the manuscript.

Funding: The APC was funded by COST CA 17133.

Institutional Review Board Statement: Not applicable.

Informed Consent Statement: Not applicable.

Data Availability Statement: Data used is contained within the article or Appendix A provided.

Acknowledgments: The work was carried out within the COST Action CA17133 Circular City ("Implementing nature-based solutions for creating a resourceful circular city", http:/ / www.circularcity.eu (accessed on 12 April 2021), duration 22 October 2018-21 October 2022). COST Actions 
are funded within the EU Horizon 2020 Programme. The authors are grateful for the support. Additionally, authors would like to thank the following colleagues that have actively participated in at least one workshop and respective discussions, and/or contributed to the collection of examples: Antonia Lorenzo (BioAzul), Attila Toth (Slovak University of Agriculture in Nitra), Fabio Masi (IRIDRA) and Natasa Atanasova (University of Ljubljana). Patrícia Vieira is grateful for her research contract funded by Fundação para a Ciência e Tecnologia (FCT) and project CENTRO-04-3559-FSE000095-Centro Portugal Regional Operational Programme (Centro2020), under the PORTUGAL 2020 Partnership Agreement, through the European Regional Development Fund (ERDF). Joaquim Comas and Gianluigi Buttiglieri acknowledge the CLEaN-TOUR project (CTM2017-85385-C2-1-R) from the Spanish Ministry of Economy and Competitiveness, Generalitat de Catalunya through Consolidated Research Group 2017-SGR-1318 and funding from CERCA programme/Generalitat de Catalunya.

Conflicts of Interest: The authors declare no conflict of interest.

\section{Appendix A}

Table A1. Case-studies, models, theories, and lab-scale of representative NBS units, exemplifying their contribution to the urban water management and the circularity challenges (UCC).

\begin{tabular}{|c|c|c|c|c|c|}
\hline NBS $^{1}$ & Type & Location & $\begin{array}{c}\text { Urban } \\
\text { Circularity } \\
\text { Challenges }^{2}\end{array}$ & $\begin{array}{l}\text { Other Contributions and } \\
\text { Ecosystem Services }\end{array}$ & Ref. \\
\hline $\begin{array}{l}\text { Infiltration basin } \\
\text { (NBS_tu) }\end{array}$ & Case-study & Ljubljana (SI) & $\begin{array}{l}\mathrm{UCC} 1 \\
\mathrm{UCC} 2\end{array}$ & & [97] \\
\hline $\begin{array}{l}\text { Infiltration trench } \\
\text { (NBS_tu) }\end{array}$ & Case-study & Málaga (ES) & $\begin{array}{l}\text { UCC1 } \\
\text { UCC2 }\end{array}$ & $\begin{array}{c}\text { Amenity } \\
\text { Biodiversity support } \\
\text { Construction community space } \\
\text { (Playscape) } \\
\text { Educational value }\end{array}$ & [98] \\
\hline $\begin{array}{l}\text { Filter drain } \\
\text { (NBS_tu) }\end{array}$ & Case-study & $\begin{array}{l}\text { Various } \\
\text { Austrian } \\
\text { cities (AT) }\end{array}$ & $\begin{array}{l}\mathrm{UCC} 1 \\
\mathrm{UCC} 2\end{array}$ & $\begin{array}{l}\text { Improved microclimate } \\
\text { Taking pressure off water collection } \\
\text { and treatment systems }\end{array}$ & [99] \\
\hline $\begin{array}{l}\text { (Wet) Retention pond } \\
\text { (NBS_tu) }\end{array}$ & Case-study & Ljubljana (SI) & $\begin{array}{l}\text { UCC1 } \\
\text { UCC2 } \\
\text { UCC6 }\end{array}$ & $\begin{array}{l}\text { Biodiversity support } \\
\text { Education } \\
\text { Recreation }\end{array}$ & [100] \\
\hline $\begin{array}{l}\text { (Dry) Retention pond } \\
\text { (NBS_tu) }\end{array}$ & Case-study & Carugo (IT) & UCC1 & $\begin{array}{c}\text { Amenity } \\
\text { Biodiversity support }\end{array}$ & [101] \\
\hline \multirow{2}{*}{$\begin{array}{l}\text { Bioretention cell } \\
\text { Rain garden } \\
\text { (NBS_tu) }\end{array}$} & Case-study & Sassuolo (IT) & $\begin{array}{l}\text { UCC1 } \\
\text { UCC2 }\end{array}$ & $\begin{array}{c}\text { Amenity } \\
\text { Improved microclimate }\end{array}$ & [101] \\
\hline & Case-study & Turin (IT) & $\begin{array}{l}\text { UCC1 } \\
\text { UCC2 }\end{array}$ & $\begin{array}{l}\text { Amenity } \\
\text { Education }\end{array}$ & [102] \\
\hline $\begin{array}{l}\text { Bioswale } \\
\text { (NBS_tu) }\end{array}$ & Case-study & Gdynia (PL) & $\begin{array}{l}\mathrm{UCC} 1 \\
\mathrm{UCC} 2\end{array}$ & Amenity & [103] \\
\hline \multirow{2}{*}{$\begin{array}{l}\text { Riparian buffer } \\
\text { (NBS_tu) }\end{array}$} & Case-study & $\begin{array}{l}\text { Scandolara } \\
\text { (IT) }\end{array}$ & $\begin{array}{l}\text { UCC1 } \\
\text { UCC2 }\end{array}$ & Biodiversity support & [104] \\
\hline & Case-study & $\begin{array}{l}\text { Mściwojów } \\
\text { (PL) }\end{array}$ & $\begin{array}{l}\text { UCC1 } \\
\text { UCC2 } \\
\text { UCC7 }\end{array}$ & Biodiversity support & [105] \\
\hline $\begin{array}{l}\text { Extensive green roof } \\
\text { (NBS_tu) }\end{array}$ & Case-study & Rende (IT) & $\begin{array}{l}\text { UCC1 } \\
\text { UCC2 } \\
\text { UCC6 } \\
\text { UCC7 }\end{array}$ & $\begin{array}{c}\text { Amenity } \\
\text { Biodiversity support } \\
\text { Building thermal performances } \\
\text { Education } \\
\text { Improved microclimate }\end{array}$ & {$[40,106,107]$} \\
\hline
\end{tabular}


Table A1. Cont.

\begin{tabular}{|c|c|c|c|c|c|}
\hline NBS $^{1}$ & Type & Location & $\begin{array}{c}\text { Urban } \\
\text { Circularity } \\
\text { Challenges }^{2}\end{array}$ & $\begin{array}{l}\text { Other Contributions and } \\
\text { Ecosystem Services }\end{array}$ & Ref. \\
\hline \multirow[t]{2}{*}{$\begin{array}{l}\text { Intensive green roof } \\
\text { (NBS_tu) }\end{array}$} & Case-study & Treviso (IT) & $\begin{array}{l}\text { UCC1 } \\
\text { UCC2 } \\
\text { UCC6 }\end{array}$ & & [79] \\
\hline & Case-study & Wrocław (PL) & $\begin{array}{l}\text { UCC1 } \\
\text { UCC2 }\end{array}$ & $\begin{array}{c}\text { Amenity } \\
\text { Education } \\
\text { Biodiversity support }\end{array}$ & [108] \\
\hline \multirow{7}{*}{$\begin{array}{l}\text { Treatment wetland } \\
\text { (NBS_tu) }\end{array}$} & Case-study & $\begin{array}{c}\text { Gorla } \\
\text { Maggiore (IT) }\end{array}$ & $\begin{array}{l}\text { UCC1 } \\
\text { UCC2 }\end{array}$ & $\begin{array}{c}\text { Amenity } \\
\text { Recreation } \\
\text { Biodiversity support }\end{array}$ & {$[89,109,110]$} \\
\hline & Case-study & Lesvos (GR) & $\begin{array}{l}\text { UCC2 } \\
\text { UCC3 } \\
\text { UCC5 } \\
\text { UCC6 }\end{array}$ & Biodiversity support & {$[24,95]$} \\
\hline & Case-study & $\begin{array}{l}\text { Mściwojów } \\
\text { (PL) }\end{array}$ & $\begin{array}{l}\text { UCC1 } \\
\text { UCC2 } \\
\text { UCC3 } \\
\text { UCC7 }\end{array}$ & Biodiversity support & [105] \\
\hline & Case-study & tba & $\begin{array}{l}\text { UCC2 } \\
\text { UCC3 } \\
\text { UCC5 } \\
\text { UCC6 }\end{array}$ & $\begin{array}{c}\text { Being gender neutral } \\
\text { Biodiversity support } \\
\text { Improved microclimate } \\
\text { Reducing carbon footprint } \\
\text { Reducing noise pollution } \\
\text { Storing nutrients from urine in } \\
\text { plant biomass } \\
\text { Working off-the-grid and being } \\
\text { Water \& energy autonomous }\end{array}$ & [111] \\
\hline & Case-study & $\begin{array}{l}\text { Lloret de Mar } \\
\quad(\mathrm{ES})\end{array}$ & $\begin{array}{l}\text { UCC1 } \\
\text { UCC2 } \\
\text { UCC3 } \\
\text { UCC6 }\end{array}$ & $\begin{array}{c}\text { Amenity } \\
\text { Biodiversity support } \\
\text { Improved microclimate } \\
\text { Education }\end{array}$ & {$[94,112]$} \\
\hline & Case-study & Nimr (OM) & $\begin{array}{l}\text { UCC2 } \\
\text { UCC3 } \\
\text { UCC4 } \\
\text { UCC5 } \\
\text { UCC6 }\end{array}$ & $\begin{array}{l}\text { Biodiversity support } \\
\text { Carbon emissions mitigation } \\
\text { Improved microclimate }\end{array}$ & [96] \\
\hline & Case-study & Mashhad (IR) & $\begin{array}{l}\text { UCC2 } \\
\text { UCC4 }\end{array}$ & Reducing carbon footprint & [113] \\
\hline $\begin{array}{l}\text { Waste stabilization } \\
\text { pond } \\
\text { (NBS_tu) }\end{array}$ & Case-study & $\begin{array}{l}\text { Vélez- } \\
\text { Málaga } \\
\text { (ES) }\end{array}$ & $\begin{array}{l}\text { UCC2 } \\
\text { UCC4 }\end{array}$ & & [114] \\
\hline $\begin{array}{l}\text { Composting } \\
\text { (NBS_i) }\end{array}$ & Model & $\operatorname{Nimr}(\mathrm{OM})$ & $\begin{array}{l}\text { UCC3 } \\
\text { UCC } 4\end{array}$ & & \\
\hline \multirow{3}{*}{$\begin{array}{l}\text { Phytoremediation } \\
\text { (NBS_i) }\end{array}$} & Case-study & Iwiny (PL) & $\begin{array}{l}\text { UCC2 } \\
\text { UCC7 }\end{array}$ & & [115] \\
\hline & Model/theory & EU & UCC7 & & [116] \\
\hline & Model/theory & EU & UCC2 & & [117] \\
\hline \multirow{2}{*}{$\begin{array}{l}\text { River restoration } \\
\text { (NBS_i) }\end{array}$} & Case-study & Łódź (PL) & $\begin{array}{l}\mathrm{UCC} 1 \\
\mathrm{UCC} 2\end{array}$ & Biodiversity support & [118] \\
\hline & Model & $\begin{array}{l}\text { Alexandria } \\
\text { (EG) }\end{array}$ & UCC2 & $\begin{array}{l}\text { Biodiversity support } \\
\text { Public health protection }\end{array}$ & [119] \\
\hline
\end{tabular}


Table A1. Cont.

\begin{tabular}{|c|c|c|c|c|c|}
\hline NBS $^{1}$ & Type & Location & $\begin{array}{c}\text { Urban } \\
\text { Circularity } \\
\text { Challenges }^{2}\end{array}$ & $\begin{array}{l}\text { Other Contributions and } \\
\text { Ecosystem Services }\end{array}$ & Ref. \\
\hline $\begin{array}{l}\text { Floodplain } \\
\text { (NBS_i) }\end{array}$ & Case-study & Poznań (PL) & UCC1 & $\begin{array}{c}\text { Recreation } \\
\text { Thermal regulation }\end{array}$ & [120] \\
\hline $\begin{array}{l}\text { Diverting and } \\
\text { deflecting elements } \\
\text { (NBS_i) }\end{array}$ & Case-study & $\begin{array}{l}\text { Jimera de } \\
\text { Líbar (ES) }\end{array}$ & UCC1 & & [114] \\
\hline $\begin{array}{l}\text { Soil reinforcement to } \\
\text { improve root cohesion } \\
\text { and anchorage } \\
\text { (NBS_i) }\end{array}$ & Case-study & $\begin{array}{l}\text { Prov. Málaga } \\
\text { (ES) }\end{array}$ & UCC1 & & [114] \\
\hline $\begin{array}{l}\text { Green corridors } \\
\text { (NBS_su) }\end{array}$ & Case-study & Nijas (ES) & UCC1 & & [114] \\
\hline $\begin{array}{l}\text { Street trees } \\
\text { (NBS_su) }\end{array}$ & Case-study & Malaga (ES) & UCC1 & & [114] \\
\hline $\begin{array}{c}\text { Pocket/garden park } \\
\text { (NBS_su) }\end{array}$ & Case-study & Wrocław (PL) & UCC1 & $\begin{array}{c}\text { Biodiversity increase } \\
\text { Aesthetic }\end{array}$ & [121] \\
\hline $\begin{array}{c}\text { Green transition zones } \\
\text { (NBS_su) }\end{array}$ & Case-study & $\begin{array}{l}\text { prov. Málaga } \\
\text { (ES) }\end{array}$ & UCC1 & & [114] \\
\hline \multirow{3}{*}{$\begin{array}{l}\text { Rainwater Harvesting } \\
\qquad\left(\mathrm{S} \_\mathrm{u}\right)\end{array}$} & Case-study & $\begin{array}{l}\text { Hedensted } \\
\quad \text { (DK) }\end{array}$ & $\begin{array}{l}\text { UCC1 } \\
\text { UCC2 } \\
\text { UCC6 }\end{array}$ & Heat island reduction & [24] \\
\hline & Case-study & Rende (IT) & $\begin{array}{l}\text { UCC1 } \\
\text { UCC2 } \\
\text { UCC4 }\end{array}$ & & [106] \\
\hline & Lab-scale & Rende (IT) & $\begin{array}{l}\mathrm{UCC} 1 \\
\mathrm{UCC} 2 \\
\mathrm{UCC} 4\end{array}$ & & {$[122,123]$} \\
\hline
\end{tabular}

\footnotetext{
${ }^{1}$ NBS units (NBS_u), which include NBS spatial units (NBS_su) and NBS technological units (NBS_tu); NBS interventions (NBS_i), which include NBS soil and river interventions (NBS_is and NBSir); and Supporting Units (S_u) ${ }^{2}$ Urban circularity challenges: UCC1, Restoring and maintaining the water cycle; UCC2, Water \& waste treatment, recovery and reuse; UCC3, Nutrient recovery and reuse; UCC4, Material recovery and reuse; UCC5, Food and biomass production; UCC6, Energy efficiency and recovery; UCC7, Building system recovery.
} 
Table A2. Case -studies, models, theories, and lab-scale of representative NBS units (Table A1) and qualitative assessment of the NBS and supportive units *

\begin{tabular}{|c|c|c|c|c|c|c|c|c|c|c|c|c|c|c|c|c|c|c|}
\hline \multirow[b]{4}{*}{ Sub-Category } & \multirow[b]{4}{*}{ NBS Unit } & \multirow[b]{4}{*}{$\begin{array}{c}\text { Total } \\
\text { Circularity } \\
\text { Score }^{1,2}\end{array}$} & \multicolumn{16}{|c|}{ Urban Circularity Challenge } \\
\hline & & & \multirow{2}{*}{\multicolumn{7}{|c|}{$\begin{array}{c}\text { UCC1: Restoring, Maintaining the Water Cycle } \\
\text { Enabling Process }\end{array}$}} & \multicolumn{9}{|c|}{ UCC2: Water-Treatment, Recovery, and Reuse } \\
\hline & & & & & & & & & & \multirow[b]{2}{*}{ 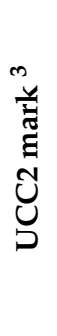 } & \multicolumn{8}{|c|}{ Enabling Process } \\
\hline & & & 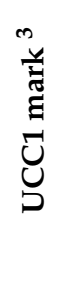 & 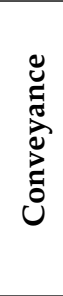 & 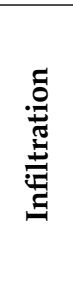 & ص̃ &  & 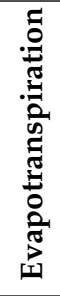 & 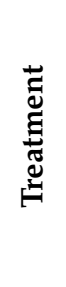 & & 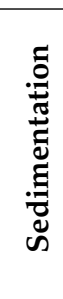 & : & 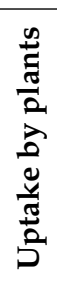 & 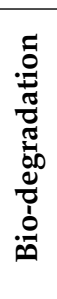 & 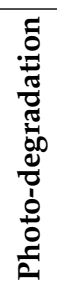 & : & 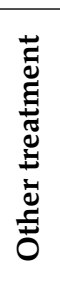 & 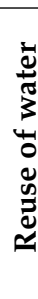 \\
\hline \multirow{11}{*}{$\begin{array}{l}\text { Units for } \\
\text { rainwater } \\
\text { management }\end{array}$} & Infiltration basin & 9 & 3 & & 3 & & & & 2 & 2 & 2 & 1 & & 1 & & 1 & & 1 \\
\hline & Infiltration trench & 7 & 3 & & 3 & & & & 1 & 1 & & 1 & & 1 & & 1 & & 1 \\
\hline & Filter strips & 10 & 3 & 3 & & & & & 2 & 2 & 2 & 2 & 2 & & & 1 & & \\
\hline & Filter drain & 8 & 3 & 3 & & & & & 2 & 2 & 1 & 2 & & 1 & & 1 & & \\
\hline & (Wet) Retention pond & 13 & 3 & & & 1 & 3 & 3 & 2 & 2 & 2 & & 1 & 1 & 2 & & & \\
\hline & (Dry) Detention pond & 7 & 3 & & & 3 & & & 2 & 2 & 2 & & 2 & & & & & \\
\hline & Bioswale & 14 & 3 & 3 & 2 & & & 3 & 3 & 3 & 1 & 1 & 3 & 1 & & & & \\
\hline & Dry swale & 6 & 3 & 3 & 2 & & & & 1 & 1 & & 1 & & & & & & \\
\hline & Tree pits & 13 & 3 & & 1 & 3 & & 3 & 2 & 3 & & 1 & 2 & & & & & 3 \\
\hline & Vegetated grid pavment & 11 & 3 & & 3 & & & 3 & 2 & 2 & & 2 & 2 & & & 1 & & \\
\hline & Riparian buffer & 19 & 3 & 3 & 3 & 3 & & 3 & 3 & 3 & 1 & 2 & 3 & & & 1 & & \\
\hline \multirow{8}{*}{$\begin{array}{l}\text { Vertical Green } \\
\text { Infrastructure \& } \\
\text { Green Roofs }\end{array}$} & Soil/ground-based green facade & 6 & 2 & & & & & 2 & 1 & 3 & & & 1 & & & & & 3 \\
\hline & Wall-based green facade & 9 & 2 & & & & & 2 & 1 & 3 & & 1 & 1 & 1 & & 1 & & 3 \\
\hline & Pot-based green facade & 9 & 2 & & & & & 2 & 1 & 3 & & 1 & 1 & 1 & & 1 & & 3 \\
\hline & Vegetated pergola & 4 & 1 & & & & & 1 & & 3 & & & & & & & & 3 \\
\hline & Extensive green roof & 6 & 3 & & & 1 & & 3 & 1 & 1 & & & 1 & & & 1 & & \\
\hline & Intensive green roof & 15 & 3 & & & 3 & & 3 & 2 & 2 & & 1 & 2 & 2 & & 2 & & 2 \\
\hline & Semi-intensive green roof & 12 & 3 & & & 2 & & 3 & 2 & 2 & & 1 & 2 & 1 & & 1 & & 2 \\
\hline & $\begin{array}{l}\text { Mobile green and vertical mobile } \\
\text { garden }\end{array}$ & 6 & 1 & & & 1 & & 1 & 1 & 3 & & & 1 & & & & & 3 \\
\hline
\end{tabular}


Table A2. Cont.

\begin{tabular}{|c|c|c|c|c|c|c|c|c|c|c|c|c|c|c|c|c|c|c|}
\hline \multirow[b]{4}{*}{ Sub-Category } & \multirow[b]{4}{*}{ NBS Unit } & \multirow[b]{4}{*}{$\begin{array}{c}\text { Total } \\
\text { Circularity } \\
\text { Score }{ }^{1,2}\end{array}$} & \multicolumn{16}{|c|}{ Urban Circularity Challenge } \\
\hline & & & \multirow{2}{*}{\multicolumn{7}{|c|}{$\begin{array}{c}\text { UCC1: Restoring, Maintaining the Water Cycle } \\
\text { Enabling Process }\end{array}$}} & \multicolumn{9}{|c|}{ UCC2: Water-Treatment, Recovery, and Reuse } \\
\hline & & & & & & & & & & \multirow[b]{2}{*}{ 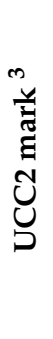 } & \multicolumn{8}{|c|}{ Enabling Process } \\
\hline & & &  &  & 泀 & \multirow{3}{*}{ 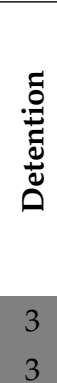 } & \multirow{3}{*}{ 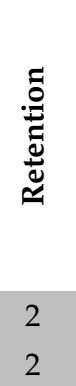 } & \multirow{3}{*}{ 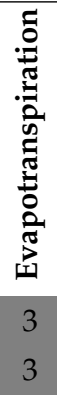 } & 离 & & 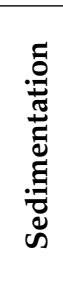 & 莺 & 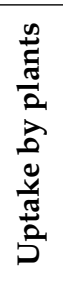 & 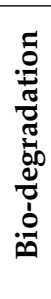 & 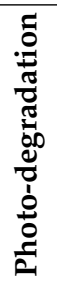 & :0ّ & 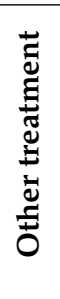 & 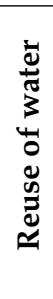 \\
\hline \multirow{6}{*}{$\begin{array}{l}\text { Remediation, } \\
\text { Treatment \& } \\
\text { Recovery }\end{array}$} & Treatment wetland & 21 & 3 & & & & & & 3 & 3 & 2 & 3 & 2 & 3 & 1 & 2 & & \\
\hline & Waste stabilisation pond & 16 & 3 & & & & & & 3 & 3 & 3 & & & 3 & 2 & & & \\
\hline & Composting & 0 & & & & & & & & & & & & & & & & \\
\hline & Bioremediation & 4 & 1 & & 1 & & & 1 & 1 & 1 & & & 1 & 1 & & & & \\
\hline & Phytoremediation & 4 & 1 & & 1 & & & 1 & 1 & 1 & & & 1 & 1 & & & & \\
\hline & $\begin{array}{l}\text { Anaerobic treatment (for nutrient, } \\
\text { VFA \& methene recovery) }\end{array}$ & 3 & 3 & & & & & & 3 & 3 & & & & 3 & & & & \\
\hline \multirow{5}{*}{$\begin{array}{c}\text { (River) } \\
\text { Restoration }\end{array}$} & River restoration & 24 & 3 & 3 & 3 & 3 & & 3 & 2 & 2 & 2 & 2 & 2 & 2 & 2 & 2 & & \\
\hline & Floodplain & 20 & 3 & 3 & 3 & 3 & & 3 & 2 & 2 & 2 & 2 & 1 & 1 & 1 & 1 & & \\
\hline & Diverting and deflecting elements & 1 & 1 & 1 & & & & & & & & & & & & & & \\
\hline & Reconnection of oxbow lake & 24 & 3 & 3 & 3 & 3 & & 3 & 2 & 2 & 2 & 2 & 2 & 2 & 2 & 2 & & \\
\hline & Coastal erosion control & 2 & 2 & 2 & & & & & & & & & & & & & & \\
\hline \multirow{4}{*}{$\begin{array}{l}\text { Soil and Water } \\
\text { Bioengineering }\end{array}$} & $\begin{array}{l}\text { Soil improvement and } \\
\text { conservation }\end{array}$ & 5 & 1 & & 1 & 1 & & & 1 & 1 & & 1 & & 1 & & 1 & & \\
\hline & Erosion control & 6 & 1 & 1 & 1 & & & 1 & 1 & 1 & & 1 & 1 & & & 1 & & \\
\hline & $\begin{array}{l}\text { Soil reinforcement to improve root } \\
\text { cohesion and anchorage }\end{array}$ & 1 & 1 & & 1 & & & & & & & & & & & & & \\
\hline & Riverbank engineering & 2 & 1 & & & & & 1 & 1 & 1 & & & 1 & & & & & \\
\hline
\end{tabular}


Table A2. Cont.

\begin{tabular}{|c|c|c|c|c|c|c|c|c|c|c|c|c|c|c|c|c|c|c|}
\hline \multirow[b]{4}{*}{ Sub-Category } & \multirow[b]{4}{*}{ NBS Unit } & \multirow[b]{4}{*}{$\begin{array}{l}\text { Total } \\
\text { Circularity } \\
\text { Score }^{1,2}\end{array}$} & \multicolumn{16}{|c|}{ Urban Circularity Challenge } \\
\hline & & & \multirow{2}{*}{\multicolumn{7}{|c|}{$\begin{array}{c}\text { UCC1: Restoring, Maintaining the Water Cycle } \\
\text { Enabling Process }\end{array}$}} & & \multicolumn{8}{|c|}{ UCC2: Water-Treatment, Recovery, and Reuse } \\
\hline & & & & & & & & & & \multirow[b]{2}{*}{ 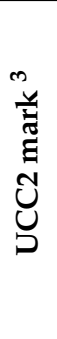 } & \multicolumn{8}{|c|}{ Enabling Process } \\
\hline & & & 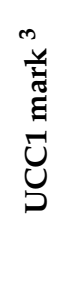 & 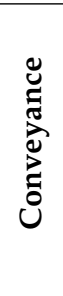 & 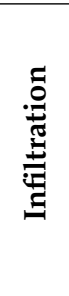 & \multirow[t]{2}{*}{  } & 泀 & \multirow[t]{2}{*}{ 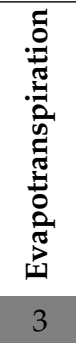 } & 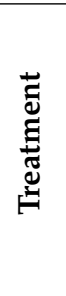 & & 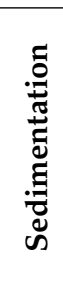 & : & 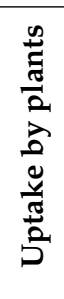 & 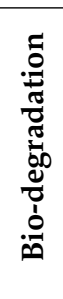 & 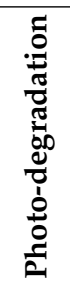 & :0ّ & 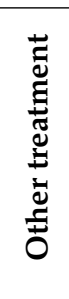 & 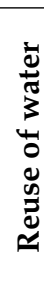 \\
\hline \multirow{6}{*}{$\begin{array}{c}\text { Greening } \\
\text { intervention + } \\
\text { (Public) Green } \\
\text { Space }\end{array}$} & Green corridors & 14 & 3 & & 3 & & & & 1 & 3 & & 1 & 1 & & & & & 3 \\
\hline & Green belt & 14 & 3 & & 3 & 3 & & 3 & 1 & 3 & & 1 & 1 & & & & & 3 \\
\hline & Street trees & 12 & 3 & & 1 & 3 & & 3 & 1 & 3 & & 1 & 1 & & & & & 3 \\
\hline & Large urban park & 14 & 3 & & 3 & 3 & & 3 & 1 & 3 & & 1 & 1 & & & & & 3 \\
\hline & Pocket/garden park & 12 & 3 & & 2 & 2 & & 3 & 1 & 3 & & 1 & 1 & & & & & 3 \\
\hline & Urban meadows & 13 & 3 & & 3 & 3 & & 2 & 1 & 3 & & 1 & 1 & & & & & 3 \\
\hline \multirow{8}{*}{$\begin{array}{l}\text { NBS units for } \\
\text { food \& biomass } \\
\text { production }\end{array}$} & Aquaculture & 1 & & & & & & & & 1 & & & & & & & & 1 \\
\hline & $\begin{array}{l}\text { Hydroponic and soilless } \\
\text { technologies }\end{array}$ & 2 & 1 & & & & & & 1 & 1 & & & 1 & & & & & 1 \\
\hline & Organoponic/Bioponic & 3 & 1 & & & & & & 1 & 1 & & & 1 & & & 1 & & 1 \\
\hline & Aquaponic farming & 6 & 2 & & & & & & 2 & 2 & 1 & & 2 & 1 & & & & 2 \\
\hline & Photo Bio Reactor & 3 & 2 & & & & & & 2 & 2 & & & & 2 & 1 & & & \\
\hline & Productive garden & 12 & 3 & & 3 & 2 & & 3 & 1 & 3 & & & 1 & & & & & 3 \\
\hline & Urban forest & 11 & 3 & & 3 & 3 & & 3 & 1 & 1 & & & 1 & & & & & 1 \\
\hline & Urban farms and orchards & 12 & 3 & & 3 & 2 & & 3 & 1 & 3 & & & 1 & & & & & 3 \\
\hline
\end{tabular}


Table A2. Cont.




Table A2. Cont.

Urban Circularity Challenge

UCC1: Restoring, Maintaining the Water Cycle $\quad$ UCC2: Water-Treatment, Recovery, and Reuse

Sub-Category

NBS Unit

Enabling Process

ircularity

Score 1,2

\begin{tabular}{|c|c|c|c|}
\hline  &  & 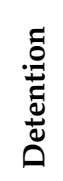 & 苞 \\
\hline
\end{tabular}

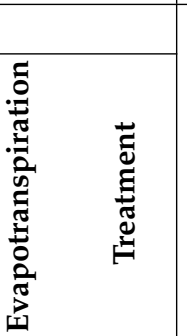

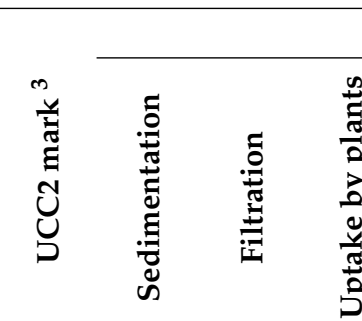

Enabling Process

\begin{tabular}{l|l|l|l|l|l}
$\begin{array}{l}\text { Advanced Oxidation Processes } \\
\text { (AOP) }\end{array}$ & 3 & 3 & 3 & 3 \\
\hline
\end{tabular}

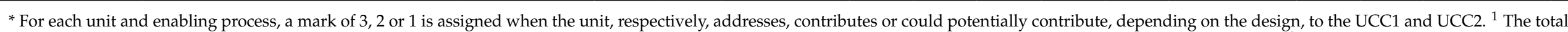

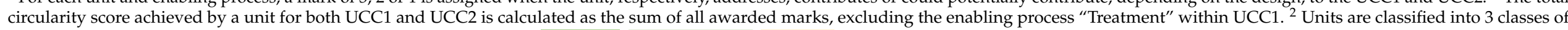

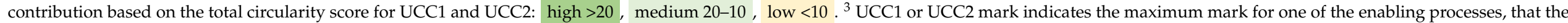
particular unit was assigned. 


\section{References}

1. Nika, C.E.; Gusmaroli, L.; Ghafourian, M.; Atanasova, N.; Buttiglieri, G.; Katsou, E. Nature-based solutions as enablers of circularity in water systems: A review on assessment methodologies, tools and indicators. Water Res. 2020, 183, 115988. [CrossRef]

2. Barbosa, R.F.S.; Souza, A.G.; Maltez, H.F.; Rosa, D.S. Chromium removal from contaminated wastewaters using biodegradable membranes containing cellulose nanostructures. Chem. Eng. J. 2020, 395, 125055. [CrossRef]

3. Mansoori, S.; Davarnejad, R.; Matsuura, T.; Ismail, A.F. Membranes based on non-synthetic (natural) polymers for wastewater treatment. Polym. Test. 2020, 84, 106381. [CrossRef]

4. McMillan, H.; Montanari, A.; Cudennec, C.; Savenije, H.; Kreibich, H.; Krueger, T.; Liu, J.; Mejia, A.; Loon, A.V.; Aksoy, H.; et al. Panta Rhei 2013-2015: Global perspectives on hydrology, society and change. Hydrol. Sci. J. 2016, 61, 1174-1191. [CrossRef]

5. Mudakkar, S.R.; Zaman, K.; Khan, M.M.; Ahmad, M. Energy for economic growth, industrialization, environment and natural resources: Living with just enough. Renew. Sustain. Energy Rev. 2013, 25, 580-595. [CrossRef]

6. Olvera, R.C.; Silva, S.L.; Robles-Belmont, E.; Lau, E.Z. Review of nanotechnology value chain for water treatment applications in Mexico. Resour. Effic. Technol. 2017, 3, 1-11. [CrossRef]

7. Xiaoming, F.; Qinglong, L.; Lichang, Y.; Fu, B.; Yongzhe, C. Linking water research with the sustainability of the human-natural system. Curr. Opin. Environ. Sustain. 2018, 33, 99-103. [CrossRef]

8. Bates, B.C.; Kundzewicz, Z.W.; Wu, S.; Palutikof, J.P. (Eds.) Climate Change and Water. Technical Paper of the Intergovernmental Panel on Climate Change; IPCC Secretariat: Geneva, Switzerland, 2008; p. 210. Available online: https://www.ipcc.ch/publication/ climate-change-and-water-2/ (accessed on 10 April 2021).

9. Finger, D.; Heinrich, G.; Gobiet, A.; Bauder, A. Projections of future water resources and their uncertainty in a glacierized catchment in the Swiss Alps and the subsequent effects on hydropower production during the 21st century. Water Resour. Res. 2012, 48, W02521. [CrossRef]

10. Snep, R.P.; Voeten, J.G.; Mol, G.; Van Hattum, T. Nature Based Solutions for Urban Resilience: A Distinction Between No-Tech, Low-Tech and High-Tech Solutions. Front. Environ. Sci. 2020, 8, 599060. [CrossRef]

11. Stefanakis, A.I.; Calheiros, C.S.C.; Nikolaou, I. Nature-Based Solutions as a Tool in the New Circular Economic Model for Climate Change Adaptation. Circ. Econ. Sustain. 2021, 1, 303-318. [CrossRef]

12. Guerra-Rodríguez, S.; Oulego, P.; Rodríguez, E.; Singh, D.N.; Rodríguez-Chueca, J. Towards the implementation of circular economy in the wastewater sector: Challenges and opportunities. Water 2020, 12, 1431. [CrossRef]

13. Neczaj, E.; Grosser, A. Circular Economy in Wastewater Treatment Plant-Challenges and Barriers. Proceedings 2018, 2, 614. [CrossRef]

14. Ma, X.; Xue, X.; González-Mejía, A.; Garland, J.; Cashdollar, J. Sustainable water systems for the city of tomorrow-A conceptual framework. Sustainability 2015, 7, 12071-12105. [CrossRef]

15. Stefanakis, A.I.; Prigent, S.; Breuer, R. Integrated produced water management in a desert oilfield using wetland technology and innovative reuse practices. In Constructed Wetlands for Industrial Wastewater Treatment; Stefanakis, A.I., Ed.; John Wiley \& Sons Ltd.: Chichester, UK, 2018; pp. 25-42.

16. Sgroi, M.; Vagliasindi, F.G.A.; Roccaro, P. Feasibility, sustainability and circular economy concepts in water reuse. Curr. Opin. Environ. Sci. Health 2018, 2, 20-25. [CrossRef]

17. Langergraber, G.; Pucher, B.; Simperler, L.; Kisser, J.; Katsou, E.; Buehler, D.; Garcia Mateo, M.C.; Atanasova, N. Implementing nature-based solutions for creating a resourceful circular city. Blue-Green Syst. 2020, 2, 173-185. [CrossRef]

18. WWAP (United Nations World Water Assessment Programme). The United Nations World Water Development Report 2018: Nature-Based Solutions; UNESCO: Paris, France, 2018.

19. Kolokotsa, D.; Santamouris, M.; Zerefos, S.C. Green and cool roofs' urban heat island mitigation potential in European climates for office buildings under free floating conditions. Sol. Energy 2013, 95, 118-130. [CrossRef]

20. Langergraber, G.; Castellar, J.A.C.; Pucher, B.; Baganz, G.F.M.; Milosevic, D.; Andreucci, M.-B.; Kearney, K.; Pineda-Martos, R.; Atanasova, N. A Framework for Addressing Circularity Challenges in Cities with Nature-based Solutions. Water 2021, 13, 2355. [CrossRef]

21. Moosavi, S.; Browne, G.R.; Bush, J. Perceptions of nature-based solutions for Urban Water challenges: Insights from Australian researchers and practitioners. Urban For. Urban Green. 2021, 57, 126937. [CrossRef]

22. Ghafourian, M.; Stanchev, P.; Mousavi, A.; Katsou, E. Economic assessment of nature-based solutions as enablers of circularity in water systems. Sci. Total Environ. 2021, 792, 148267. [CrossRef]

23. Hemming, V.; Walshe, T.; Hanea, A.; Fidler, F.; Burgman, M. Eliciting improved quantitative judgements using the IDEA protocol: A case study in natural resource management. PLoS ONE 2018, 13, e0198468. [CrossRef]

24. Oral, H.V.; Carvalho, P.; Gajewska, M.; Ursino, N.; Masi, F.; van Hullebusch, E.D.; Kazak, J.; Exposito, A.; Cipolletta, G.; Andersen, T.R.; et al. A Review of Nature Based Solutions for Urban Water Management in European Circular Cities: A critical assessment based on case studies and literature. Blue-Green Syst. 2020, 2, 112-136. [CrossRef]

25. Pérez-Carrión, M.; Baeza-Brotons, F.; Payá, J.; Saval, J.M.; Zornoza, E.; Borrachero, M.V.; Garcés, P. Potential Use of Sewage Sludge Ash (SSA) As a Cement Replacement in Precast Concrete Blocks. Mat. Const. 2014, 64, 313. [CrossRef] 
26. Joensuu, T.; Edelman, H.; Saari, A. Circular economy practices in the built environment. J. Clean. Prod. 2020, $276,124215$. [CrossRef]

27. Lepeška, T. The Impact of Impervious Surfaces on Ecohydrology and Health in Urban Ecosystems of Banská Bystrica (Slovakia). Soil Water Res. 2016, 11, 29-36. [CrossRef]

28. Berndtsson, R.; Becker, P.; Persson, A.; Aspegren, H.; Haghighatafshar, S.; Jönsson, K.; Larsson, R.; Mobini, S.; Mottaghi, M.; Nilsson, J.; et al. Drivers of changing urban flood risk: A framework for action. J. Environ. Manag. 2019, 240, 47-56. [CrossRef] [PubMed]

29. Kozak, D.; Henderson, H.; de Castro Mazarro, A.; Rotbart, D.; Aradas, R. Blue-Green Infrastructure (BGI) in Dense Urban Watersheds. The Case of the Medrano Stream Basin (MSB) in Buenos Aires. Sustainability 2020, 12, 2163. [CrossRef]

30. Foster, S. Global policy overview of groundwater in Urban development-A tale of 10 cities! Water 2020, 12, 456. [CrossRef]

31. Alves, A.; Gersonius, B.; Sanchez, A.; Vojinovic, Z.; Kapelan, Z. Multi-criteria Approach for Selection of Green and Grey Infrastructure to Reduce Flood Risk and Increase CO-benefits. Water Resour. Manag. 2018, 32, 2505-2522. [CrossRef]

32. Keesstra, S.; Nunes, J.; Novara, A.; Finger, D.; Avelar, D.; Kalantari, Z.; Cerdà, A. The superior effect of nature based solutions in land management for enhancing ecosystem services. Sci. Total Environ. 2017, 610, 997-1009. [CrossRef] [PubMed]

33. European Environment Agency (EEA). Exploring Nature-Based Solutions-The Role of Green Infrastructure in Mitigating the Impacts of Weather- and Climate Change-Related Natural Hazards; Publications Office of the European Union: Luxembourg, 2015.

34. Imran, H.M.; Kala, J.; Ng, A.; Muthukumaran, S. Effectiveness of vegetated patches as Green Infrastructure in mitigating Urban Heat Island effects during a heatwave event in the city of Melbourne. Weather Clim. Extremes 2019, 25, 100217. [CrossRef]

35. Ferrini, F.; Fini, A.; Mori, J.; Gori, A. Role of Vegetation as a Mitigating Factor in the Urban Context. Sustainability 2020, $12,4247$. [CrossRef]

36. Ecosystem Services of Urban Agriculture: Perceptions of Project Leaders, Stakeholders and the General Public. Sustainability 2020, 12, 10446. [CrossRef]

37. Stovin, V.; Poë, S.; Berretta, C. A modelling study of long term green roof retention performance. J. Environ. Manag. 2013, 131, 206-215. [CrossRef]

38. Calheiros, C.S.C.; Stefanakis, A.I. Green Roofs Towards Circular and Resilient Cities. Circ. Econ. Sustain. 2021 1, $395-411$. [CrossRef]

39. Liu, W.; Feng, Q.; Chen, W.; Wei, W.; Deo, R.C. The influence of structural factors on stormwater runoff retention of extensive green roofs: New evidence from scale-based models and real experiments. J. Hydrol. 2019, 569, 230-238. [CrossRef]

40. Palermo, S.A.; Turco, M.; Principato, F.; Piro, P. Hydrological effectiveness of an extensive green roof in Mediterranean climate. Water 2019, 11, 1378. [CrossRef]

41. Tahvonen, O. Scalable Green Infrastructure-The Case of Domestic Private Gardens in Vuores, Finland. Sustainability 2018, 10, 4571. [CrossRef]

42. Masi, F.; Rizzo, A.; Regelsberger, M. The role of constructed wetlands in a new circular economy, resource oriented, and ecosystem services paradigm. J. Environ. Manag. 2018, 216, 275-284. [CrossRef]

43. Stefanakis, A.I. The role of constructed wetlands as green infrastructure for sustainable urban water management. Sustainability 2019, 11, 6981. [CrossRef]

44. Alamdari, N.; Sample, D.J.; Steinberg, P.; Ross, A.C.; Easton, Z.M. Assessing the Effects of Climate Change on Water Quantity and Quality in an Urban Watershed Using a Calibrated Stormwater Model. Water 2017, 9, 464. [CrossRef]

45. Quinn, R.; Rougé, C.; Stovin, V. Quantifying the performance of dual-use rainwater harvesting systems. Water Res. X 2021, 10, 100081. [CrossRef] [PubMed]

46. Wilcox, J.; Nasiri, F.; Bell, S.; Rahaman, M.S. Urban water reuse: A triple bottom line assessment framework and review. Sustain. Cities Soc. 2016, 27, 448-456. [CrossRef]

47. Kisser, J.; Wirth, M.; De Gusseme, B.; Van Eekert, M.; Zeeman, G.; Schoenborn, A.; Beesley, L. A review of nature-based solutions for resource recovery in cities. Blue-Green Syst. 2020, 2, 138-172. [CrossRef]

48. Finger, D.; Schmid, M.; Wüest, A. Comparing effects of oligotrophication and upstream hydropower dams on plankton and productivity in perialpine lakes. Water Resour. Res. 2007, 43, 1-18. [CrossRef]

49. Hoffmann, S.; Feldmann, U.; Bach, P.M.; Binz, C.; Farrelly, M.; Frantzeskaki, N.; Udert, K.M. A Research Agenda for the Future of Urban Water Management: Exploring the Potential of Nongrid, Small-Grid, and Hybrid Solutions. Environ. Sci. Technol. 2020, 54, 5312-5322. [CrossRef] [PubMed]

50. Kehrein, P.; Loosdrecht, M.V.; Osseweijer, P.; Garfí, M.; Dewulf, J.; Posada, J. A critical review of resource recovery from municipal wastewater treatment plants-Market supply potentials, technologies and bottlenecks. Environ. Sci. Water Res. Technol. 2020, 6, 877-910. [CrossRef]

51. Alayish, O.; Çelik, T. Extending disposal route of dewatered sewage sludge produced from the new wastewater treatment plant in Nicosia toward sustainable building materials. Environ. Earth Sci. 2021, 80, 146. [CrossRef]

52. International Water Association (IWA). Water Utility Pathways in a Circular Economy. 2016. Available online: https://www.iwanetwork.org/wp-content/uploads/2016/07/IWA_Circular_Economy_screen.pdf (accessed on 13 May 2021).

53. Skar, S.L.G.; Pineda-Martos, R.; Timpe, A.; Pölling, B.; Bohn, K.; Külvik, M.; Junge, R. Urban agriculture as a keystone contribution towards securing sustainable and healthy development for cities in the future. Blue-Green Syst. 2020, 2, 1-27. [CrossRef] 
54. Fenner, R. Spatial evaluation of multiple benefits to encourage multi-functional design of sustainable drainage in Blue-Green cities. Water 2017, 9, 953. [CrossRef]

55. Emmanuel, R.; Loconsole, A. Green infrastructure as an adaptation approach to tackling urban overheating in the Glasgow Clyde Valley Region, UK. Landsc. Urban Plan. 2015, 138, 71-86. [CrossRef]

56. Scott, C.A.; Pierce, S.A.; Pasqualetti, M.J.; Jones, A.L.; Montz, B.E.; Hoover, J.H. Policy and institutional dimensions of the water-energy nexus. Energy Policy 2011, 39, 6622-6630. [CrossRef]

57. Carvalho, P.N.; Finger, D.C.; Masi, F.; Cipollettta, G.; Oral, H.V.; Tóth, A.; Regelsberger, M.; Exposito, A. Nature-based solutions addressing the water-energy-food nexus: Review of theoretical concepts and case studies. J. Clean. Prod. Under Rev.. in press.

58. Li, X.; Feng, K.; Siu, Y.L.; Hubacek, K. Energy-water nexus of wind power in China: The balancing act between $\mathrm{CO}_{2}$ emissions and water consumption. Energy Policy 2012, 45, 440-448. [CrossRef]

59. Zhang, C.; Chen, X.; Li, Y.; Ding, W.; Fu, G. Water-energy-food nexus: Concepts, questions and methodologies. J. Clean. Prod. 2018, 195, 625-639. [CrossRef]

60. Chow, W.L.; Chong, S.; Lim, J.W.; Chan, Y.J.; Chong, M.F.; Tiong, T.J.; Chin, J.K.; Pan, G.-T. Anaerobic Co-Digestion of Wastewater Sludge: A Review of Potential Co-Substrates and Operating Factors for Improved Methane Yield. Processes 2020, 8, 39. [CrossRef]

61. El Gnaoui, Y.; Sounni, F.; Bakraoui, M.; Karouach, F.; Benlemlih, M.; Barz, M.; El Bari, H. Anaerobic co-digestion assessment of olive mill wastewater and food waste: Effect of mixture ratio on methane production and process stability. J. Environ. Chem. Eng. 2020, 8, 103874. [CrossRef]

62. Park, K.Y.; Jang, H.M.; Park, M.-R.; Lee, K. Combination of different substrates to improve anaerobic digestion of sewage sludge in a wastewater treatment plant. Int. Biodeter. Biodegrad. 2016, 109, 73-77. [CrossRef]

63. Fogarassy, C.; Toth, L.; Czikkely, M.; Finger, D.C. Improving the Efficiency of Pyrolysis and Increasing the Quality of Gas Production through Optimization of Prototype Systems. Resources 2019, 8, 182. [CrossRef]

64. Llano, T.; Arce, C.; Finger, D.C. Optimization of biogas production through anaerobic digestion of municipal solid waste: A case study in the capital area of Reykjavik, Iceland. J. Chem. Technol. Biotechnol. 2021, 96, 1333-1344. [CrossRef]

65. Radić, M.; Brković Dodig, M.; Auer, T. Green Facades and Living Walls-A Review Establishing the Classification of Construction Types and Mapping the Benefits. Sustainability 2019, 11, 4579. [CrossRef]

66. Coma, J.; Pérez, G.; Solé, C.; Castell, A.; Cabeza, L.F. Thermal assessment of extensive green roofs as passive tool for energy savings in buildings. Renew. Energy 2016, 85, 1106-1115. [CrossRef]

67. Maiolo, M.; Pirouz, B.; Bruno, R.; Palermo, S.A.; Arcuri, N.; Piro, P. The role of the extensive green roofs on decreasing building energy consumption in the mediterranean climate. Sustainability 2020, 12, 359. [CrossRef]

68. Pirouz, B.; Palermo, S.A.; Maiolo, M.; Arcuri, N.; Piro, P. Decreasing water footprint of electricity and heat by extensive green roofs: Case of southern italy. Sustainability 2020, 12, 10178. [CrossRef]

69. Pearlmutter, D.; Theochari, D.; Nehls, T.; Pinho, P.; Piro, P.; Korolova, A.; Papaefthimioy, S.; Mateo, M.C.G.; Calheiros, C.; Zluwai, I.; et al. Enhancing the circular economy with nature-based solutions in the built urban environment: Green building materials, systems and sites. Blue-Green Syst. 2020, 2, 46-72. [CrossRef]

70. David, P. Path Dependence, its Critics, and the Quest for 'Historical Economics'. In The Evolution of Economic Institutions; Edward Elgar Publishing: Northampton, MA, USA, 2007; Available online: https:/ /EconPapers.repec.org/RePEc:elg:eechap:12603_7 (accessed on 10 May 2021).

71. Mattila, H. Appropriate Management of On-Site Sanitation; Publication 537; Tampere University of Technology: Tampere, Finland, 2005; ISBN 952-15-1370-5.

72. World Water Development Report 2018. Available online: https://www.unwater.org/publications/world-water-developmentreport-2018/ (accessed on 16 June 2021).

73. Ursino, N. Dynamic models of socio-ecological systems predict catastrophic shifts following unsustainable development. Sci. Total Environ. 2019, 654, 890-894. [CrossRef]

74. Schröter, B.; Zingraff-Hamed, A.; Ott, E.; Huang, J.; Hüesker, F.; Nicolas, C.; Schröder, N.J.S. The knowledge transfer potential of online data pools on nature-based solutions. Sci. Total Environ. 2021, 762, 143074. [CrossRef]

75. Acuña, V.; Castañares, L.; Castellar, J.A.C.; Comas, J.; Corominas, L.; Cross, K.; McDonald, R.; Riu, A. Development and testing of a decision-support system to facilitate the implementation of nature-based solutions for urban water sanitation. Water Res. 2021. in preparation.

76. Castellar, J.A.C.; Popartan, L.A.; Pueyo-Ros, J.; Atanasova, N.; Langergraber, G.; Säumel, J.; Corominas, L.; Comas, J.; Acuña, V. Nature-based solutions in the urban context: Terminology, classification and scoring for urban challenges and ecosystem services. Sci. Total Environ. 2021, 779, 146237. [CrossRef]

77. Mikos, M.; Kranjc, A.; Maticic, B.; Müller, J.; Rakovec, J.; Ros, M.; Brilly, M. Hidrološko izrazje/Terminiology in hydrology. Acta Hydrotechnol. 2002, 20, 3-324. Available online: https://actahydrotechnica.fgg.uni-lj.si/en/paper/a32_1 (accessed on 15 May 2021).

78. Tchobanoglous, G.; Burton, F.; Stensel, H.D. Wastewater Engineering: Treatment and Reuse, 5th ed.; McGraw-Hill Higher Education: Boston, MA, USA, 2014.

79. Masi, F.; Rizzo, A.; Bresciani, R. Green architecture and water reuse: Examples from different countries. Sustain. Sanit. Pract. 2015, 23, 4-10. 
80. Halecki, W.; Stachura, T. Evaluation of soil hydrophysical parameters along a semiurban small river: Soil ecosystem services for enhancing water retention in urban and suburban green areas. CATENA 2021, 196, 104910. [CrossRef]

81. Kolokotsa, D.; Lilli, A.A.; Nikolaidis, N.P. On the impact of nature-based solutions on citizen's health \& well being. Energy Build. 2020, 229, 110542.

82. Maes, J.; Liquete, C.; Teller, A.; Erhard, M.; Paracchini, M.L.; Barredo, J.I.; Grizzetti, B.; Cardoso, A.; Somma, F.; Petersen, J.E.; et al. An indicator framework for assessing ecosystem services in support of the EU Biodiversity Strategy to 2020. Ecosyst. Serv. 2016, 17, 14-23. [CrossRef]

83. Raymond, C.M.; Frantzeskaki, N.; Kabisch, N.; Berry, P.; Breil, M.; Nita, M.R.; Geneletti, D.; Calfapietra, C. A framework for assessing and implementing the co-benefits of nature-based solutions in urban areas. Environ. Sci. Policy 2017, 77, 15-24. [CrossRef]

84. Urbangreenup. Available online: https://www.urbangreenup.eu/news--events/news/the-urban-greenup-catalogue-of-naturebased-solutions-is-now-public_1.kl (accessed on 16 June 2021).

85. Somarakis, G.; Stagakis, S.; Chrysoulakis, N. ThinkNature Nature Based Solutions Handbook; ThinkNature Project Funded by the EU Horizon 2020 Research and Innovation Programme; ThinkNature: Hague, The Netherlands, 2019; Volume 730338, pp. 1-226. Available online: https: / / doi.org/10.26225/jerv-w202 (accessed on 1 August 2021).

86. Urban Nature Labotaries (UNALAB). Available online: https://unalab.eu/en/documents/unalab-technical-handbook-naturebased-solutions (accessed on 15 June 2021).

87. Directorate-General for Research and Innovation (European Commission). Evaluating the Impact of Nature-Based Solutions: A Handbook for Practitioners, 1st ed.; Publications Office of the European Union: Luxembourg, 2021; ISBN 978-92-76-22821-9. [CrossRef]

88. Evaluating the Impact of Nature-Based Solutions: A Handbook for Practitioners. Available online: https:/ / ec.europa.eu/info/ news/evaluating-impact-nature-based-solutions-handbook-practitioners-2021-may-06_en (accessed on 21 November 2021).

89. Liquete, C.; Udias, A.; Conte, G.; Grizzetti, B.; Masi, F. Integrated valuation of a nature-based solution for water pollution control. Highlighting hidden benefits. Ecosyst. Serv. 2016, 22, 392-401. [CrossRef]

90. Rizzo, A.; Conte, G.; Masi, F. Adjusted Unit Value Transfer as a Tool for Raising Awareness on Ecosystem Services Provided by Constructed Wetlands for Water Pollution Control: An Italian Case Study. Int. J. Environ. Res. Public Health 2021, $18,1531$. [CrossRef]

91. Kazak, J.K.; Chruściński, J.; Szewrański, S. The Development of a Novel Decision Support System for the Location of Green Infrastructure for Stormwater Management. Sustainability 2018, 10, 4388. [CrossRef]

92. Kapos, V.; Wicander, S.; Salvaterra, T.; Dawkins, K.; Hicks, C. The Role of the Natural Environment in Adaptation, Background Paper for the Global Commission on Adaptation; Global Commission on Adaptation: Rotterdam, The Netherlands; Washington, DC, USA, 2019.

93. De Lamo, X.; Jung, M.; Visconti, P.; Schmidt-Traub, G.; Miles, L.; Kapos, V. Strengthening Synergies: How Action to Achieve Post-2020 Global Biodiversity Conservation Targets Can Contribute to Mitigating Climate Change; UNEP-WCMC: Cambridge, MA, USA, 2020.

94. Estelrich, M.; Vosse, J.; Comas, J.; Atanasova, N.; Costa, J.C.; Gattringer, H.; Buttiglieri, G. Feasibility of vertical ecosystem for sustainable water treatment and reuse in touristic resorts. J. Environ. Manag. 2021, 294, 112968. [CrossRef]

95. Masi, F.; Langergraber, G.; Santoni, M.; Istenič, D.; Atanasova, N.; Buttiglieri, G. Possibilities of nature-based and hybrid decentralized solutions for reclaimed water reuse. In Advances in Chemical Pollution, Environmental Management and Protection; Verlicchi, P., Ed.; Elsevier: Amsterdam, The Netherlands, 2020; pp. 145-187. ISBN 978-0-128-20170-1.

96. Stefanakis, A.I. Constructed Wetlands for Sustainable Wastewater Treatment in Hot and Arid Climates: Opportunities, Challenges and Case Studies in the Middle East. Water 2020, 12, 1665. [CrossRef]

97. Klemen, K.; Pergar, P.; Fatur, M.; Šekoranja, B.B.; Konda, K. The issues of planning nature-based solutions for the integrated stormwater management in urban areas. Gradb. Vestn. 2020, 3, 73-81.

98. Green-Blue SUD Project at Luis Buñuel Educational Center. Available online: https://paisajesresilientes.wordpress.com/2019/0 5/25/verde-azul_proyecto-de-drenaje-urbano-sostenible-dus-en-ceip-luis-bunuel-green-bluish_suds-project-in-school-luisbunuel/ (accessed on 13 June 2021).

99. Allabashi, R.; Haile, T.M.; Fuerhacker, M.; Pitha, U.; Scharf, B.; Stach, W.; Ziegenbalg, F.; Heidinger, S.; Ertl, T. Simultaneous removal of heavy metals from synthetic storm water using sustainable urban drainage systems. Urban Water J. 2019, 16, 444-450. [CrossRef]

100. Bulc, T.; Istenič, D.; Klemenčič, A.K. Case study 8-Multifunctional water reservoir in Lubliana (Slovenia), Chapter 6.9. In Wetland Technology: Practical Information on Design and Application of Treatment Wetlands; Langergraber, G., Dotro, G., Nivala, J., Rizzo, A., Stein, O., Eds.; IWA Publishing: London, UK, 2019; pp. 5-9. ISBN 978-1-789-06016-4.

101. IRIDRA Webpage. Available online: http:/ / www.iridra.com (accessed on 13 June 2021).

102. Interreg CWC Project. Available online: https://www.interreg-central.eu/Content.Node/CWC.html (accessed on 13 June 2021).

103. Rain Garden Project. Available online: https://www.gdynia.pl/co-nowego,2774/powstanie-ogrod-deszczowy-na-meksyku,51 8698 (accessed on 13 June 2021).

104. Gumiero, B.; Boz, B. How to stop nitrogen leaking from a Cross complaint buffer strip? Ecolog. Eng. 2017, 103, 446-454. [CrossRef] 
105. Dąbrowska, J.; Kaczmarek, H.; Markowska, J.; Tyszkowski, S.; Kempa, O.; Gałęza, M.; Kucharczak-Moryl, E.; Moryl, A. Shore zone in protection of water quality in agricultural landscape-the Mściwojów Reservoir, southwestern Poland. Environ. Monit. Assess. 2016, 188, 1-14. [CrossRef] [PubMed]

106. Brunetti, G.; Šimůnek, J.; Piro, P. A Comprehensive Analysis of the Variably Saturated Hydraulic Behavior of a Green Roof in a Mediterranean Climate. Vadose Zone J. 2016, 15, vzj2016.04.0032. [CrossRef]

107. Brunetti, G.; Porti, M.; Piro, P. Multi-level numerical and statistical analysis of the hygrothermal behavior of a non-vegetated green roof in a mediterranean climate. Appl. Energy 2018, 221, 204-219. [CrossRef]

108. The Green Gardens of Wroclavia as a Model for Other European Cities. Available online: https://www.wroclaw.pl/ przedsiebiorczy-wroclaw/zielone-ogrody-wroclavii (accessed on 13 June 2021).

109. Masi, F.; Bresciani, R.; Rizzo, A.; Conte, G. Constructed wetlands for combined sewer overflow treatment: Ecosystem services at Gorla Maggiore, Italy. Ecolog. Eng. 2017, 98, 427-438. [CrossRef]

110. Rizzo, A.; Bresciani, R.; Masi, F.; Boano, F.; Revelli, R.; Ridolfi, L. Flood reduction as an ecosystem service of constructed wetlands for combined sewer overflow. J. Hydrol. 2018, 560, 150-159. [CrossRef]

111. Loopi Project. Available online: https:/ / www.alchemia-nova.net/projects/loopi/ (accessed on 19 May 2021).

112. Zraunig, A.; Estelrich, M.; Gattringer, H.; Kisser, J.; Langergraber, G.; Radtke, M.; Rodriguez-Roda, I.; Buttiglieri, G. Long term decentralized greywater treatment for water reuse purposes in a tourist facility by Vertical Ecosystem. Ecolog. Eng. 2019, 138, 138-147. [CrossRef]

113. Gholipour, A.; Zahabi, H.; Stefanakis, A.I. A novel pilot and full-scale constructed wetland study for glass industry wastewater treatment. Chemosphere 2020, 247, 125966. [CrossRef]

114. International Union for the Nature Conservation. Catalogue Developed by the Cluster of Nature Based Solutions of Malaga (SbN Cluster); UNIA Summer Course; International Union for the Nature Conservation: Málaga, Spain, 2021; ISBN 978-84-09-28296-8

115. Kuc, P.; Kordas, L.; Lejcuś, K. Phytostabilisation of tailing ponds with use of water absorbing geocomposites and organic and mineral additives. Environ. Protect. Eng. 2019, 45, 71-81. [CrossRef]

116. Kidd, P.S.; Bani, A.; Benizri, E.; Gonnelli, C.; Hazotte, C.; Kisser, J.; Konstantinou, M.; Kuppens, T.; Kyrkas, D.; Laubie, B.; et al. Developing sustainable agromining systems in agricultural ultramafic soils for nickel recovery. Front. Environ. Sci. $2018,6,44$. [CrossRef]

117. Rosenkranz, T.; Kisser, J.; Wenzel, W.W.; Puschenreiter, M. Waste or substrate for metal hyperaccumulating plants-the potential of phytomining on waste incineration bottom ash. Sci. Total Environ. 2017, 575, 910-918. [CrossRef]

118. Bedla, D.; Halecki, W. The value of river valleys for restoring landscape features and the continuity of urban ecosystem functions-A review. Ecol. Indic. 2021, 129, 107871. [CrossRef]

119. Gaballah, M.S.; Ismail, K.; Aboagye, D.; Ismail, M.M.; Sobhi, M.; Stefanakis, A.I. Effect of design and operational parameters on nutrients and heavy metals removal in pilot Floating Treatment Wetlands with Eichhornia Crassipes treating polluted lake water. Environ. Sci. Pollut. Res. 2021, 28, 25664-25678. [CrossRef] [PubMed]

120. Development of Flood Plain of Warta River. Available online: https:/ / connectingnature.eu/oppla-case-study/19386 (accessed on 15 June 2021).

121. Pocket Parks. Available online: https://www.wroclaw.pl/growgreen/en/pocket-parks (accessed on 15 June 2021).

122. Turco, M.; Kodešová, R.; Brunetti, G.; Nikodem, A.; Fér, M.; Piro, P. Unsaturated hydraulic behaviour of a permeable pavement: Laboratory investigation and numerical analysis by using the HYDRUS-2D model. J. Hydrol. 2017, 554. [CrossRef]

123. Turco, M.; Brunetti, G.; Palermo, S.A.; Capano, G.; Grossi, G.; Maiolo, M.; Piro, P. On the environmental benefits of a permeable pavement: Metals potential removal efficiency and Life Cycle Assessment. Urban Water J. 2020, 17, 619-627. [CrossRef] 